\title{
Geostrophic ocean currents and freshwater fluxes across the Canadian polar shelf via Nares Strait
}

\author{
by Berit Rabe ${ }^{1,2,3}$, Helen L. Johnson ${ }^{4}$, Andreas Münchow ${ }^{1}$ and Humfrey Melling ${ }^{5}$
}

\begin{abstract}
This study discusses geostrophic ocean currents and fluxes through Nares Strait, one of the major straits connecting the Arctic Ocean to the North Atlantic across the Canadian polar shelf. Between 2003 and 2006, instruments were installed on subsea moorings to measure conductivity, temperature, pressure and velocity at high temporal and spatial resolution across the 400-m-deep strait.

Here we present estimates of the variable volume and liquid freshwater fluxes, derived by geostrophic calculation, through the fraction of the cross section measured by the array. The array of conductivity-temperature recorders spanned $30 \mathrm{~km}$ of a 38-km-wide section between 30- and 200-m depth. This domain is $48 \%$ of the total cross-sectional area, and $74 \%$ of the cross-sectional area above 200-m depth. We demonstrate the importance of the seasonal alternation between land-fast and mobile-ice conditions, which has a strong influence on the structure of the geostrophic flow and the fluxes carried by it.

The three-year mean geostrophic freshwater flux through the measured domain was $20 \pm 3 \mathrm{mSv}$ (relative to $34.8 \mathrm{psu}$ ) and no less than $28 \mathrm{mSv}$ if extrapolated to the surface. No significant trend over three years was detected, but the flux of freshwater through the measured domain was about $20 \%$ larger when ice was moving than when it was land-fast, with a maximum difference between individual ice seasons of $40 \%$. Geostrophic freshwater flux in Nares Strait was forced by both wind and alongchannel pressure difference during mobile-ice periods, and by along-channel pressure difference only under land-fast ice. Local winds and along-channel pressure differences explained $80 \%$ of the flux variance.

Geostrophic volume flux through the measured domain was less strongly influenced by the state of the ice; its three-year mean was $0.47 \pm 0.05 \mathrm{~Sv}$, with a statistically significant increase of $15 \pm 4 \%$ over this time. Geostrophic velocity was highly variable in space and time. The flow structure changed from a pattern with a surface jet in the center of the channel during mobile-ice conditions to another with a subsurface maximum in velocity adjacent to Ellesmere Island during fast-ice conditions. Over the three years, a second jet developed adjacent to the Ellesmere coast during mobile-ice regimes. Strong freshwater incursions synchronous with strong wind events were observed during mobile-ice seasons in the western half of the strait.
\end{abstract}

1. University of Delaware, Newark, Delaware, U.S.A.

2. Current address: Marine Laboratory, Marine Scotland Science, Aberdeen, United Kingdom.

3. Corresponding author.email: rabe@marlab.ac.uk

4. University of Oxford, Oxford, United Kingdom.

5. Institute of Ocean Sciences, Sidney, British Columbia, Canada. 


\section{Introduction}

The Arctic Ocean freshwater budget influences the global climate system. Studies of different components of the budget originated in the 1960s by Timofeev (1960) and Mosby (1962) and continue until today (Aagaard and Carmack, 1989; Serreze et al., 2006; White et al., 2007). Important parts of the freshwater budget are the Pacific Water inflow through Bering Strait, Atlantic Water inflow through the Barents Sea and Fram Strait, continental river runoff, precipitation-evaporation, and outflow of liquid water and ice through Fram Strait and the Canadian Arctic Archipelago (CAA). Freshwater storage, especially in the Beaufort Gyre, means that the budget does not have to balance at any given time; pulses of freshwater release can occur in association with transitions between climate regimes (Proshutinsky et al., 2009). When freshwater is released from the Arctic Ocean to the North Atlantic, it can influence deep water formation and therefore the Meridional Overturning Circulation (Lazier, 1980; Hakkinen, 1993, 1999; Rennermalm et al., 2006; Stouffer et al., 2006; Wu et al., 2008).

Significant changes have recently been observed in the Arctic in sea-ice drift pattern and upper ocean circulation (Polyakov and Johnson, 2000; Rigor et al., 2002), in sea-ice cover (Lindsay and Zhang, 2005; Stroeve et al., 2005; Lindsay et al., 2009), in the Atlantic inflow through Fram Strait (Holliday et al., 2008), in run-off into the Eurasian sector (Peterson et al., 2002), and in sea-ice export through Nares Strait (Kwok et al., 2010). All these changes can influence the freshwater cycle; most changes correlate with atmospheric forcing (Serreze and Francis, 2006).

To improve budget calculations and to investigate its variations, long-term measurements of all budget components are necessary. The CAA poses several challenges for long-term monitoring, such as a land-fast ice cover for up to eight months of the year, its closeness to the magnetic North Pole, and remote location (Melling, 2000). Observations in the CAA include data from Lancaster Sound, Barrow Strait, Cardigan Strait, Hells Gate, Wellington Channel, Hudson Strait, Nares Strait, and Davis Strait (Melling, 2004; Prinsenberg and Hamilton, 2005; Cuny et al., 2005; Müenchow et al., 2006; 2007; Müenchow and Milling, 2008; Straneo and Saucier 2008; Curry et al., 2011).

This study focuses on Nares Strait, between the northern Canadian Archipelago and Greenland (Fig. 1), where existing knowledge is scarce. Sadler (1976) deployed current meters for 40 days in the early 1970s, Bourke et al. (1989) investigated temperature and salinity during one summer season in the 1980s, and Müenchow et al. (2006) and Müenchow et al. (2007) evaluated data from two-day (ADCP) surveys in 2003. Between 2003 and 2006, the moorings that resulted in the data described here were deployed in Nares Strait to investigate variability on tidal to interannual timescales for the first time. Müenchow and Melling (2008) published the first results of the vertically averaged current variability, while Samelson and Barbour (2008) discussed results from the atmospheric modeling component of the project. Rabe et al. (2010) investigated the hydrography and salinity field for the 3 years.

As well as being crucial for an improved understanding of ocean dynamics in the region, measurements of current, wind and hydrography are also essential for determining reliable 

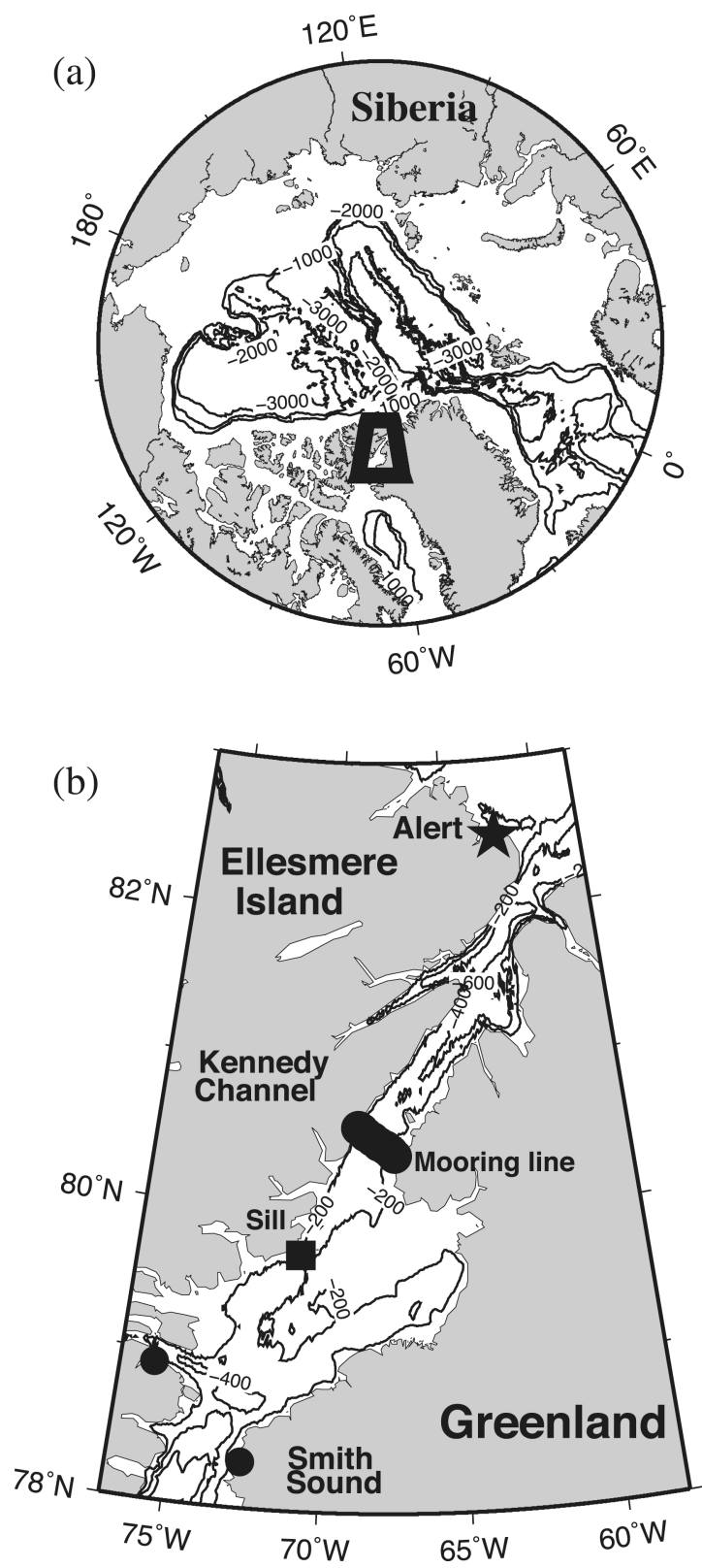

Figure 1. Study area. (a) Arctic Ocean bottom topography with Nares Strait highlighted. (b) Nares Strait bottom topography with thick black line denoting mooring line in Kennedy Channel. Black circles represent recovered subsurface pressure moorings in Foulke Fjord on the Greenland side and Alexandra Fjord on the Ellesmere Island (Canada) side. The star denotes the location of a tide gauge at Alert in northeastern Ellesmere Island. Smith Sound lies to the south of Nares Strait and has a sill depth of $230 \mathrm{~m}$ (black square). 
fluxes and their variation in Nares Strait. Observed changes in volume and freshwater fluxes can provide solid evidence of environmental change and are useful in constraining the predictions of forecast models. Many current climate models allow no flow of water across the Canadian polar shelf, despite evidence that accommodating such outflows improves model performance (Holland et al., 2007). Fluxes through Nares Strait also reflect impacts of diminishing sea ice in the Arctic (Parkinson and Cavalieri, 2008), disintegrating ice shelves in northern Canada (Copland et al., 2007), and potentially surging glaciers and ice loss from the ice sheet in northern Greenland (Rignot and Steffen, 2008; Khan et al., 2010; Johnson et al., 2011).

Nares Strait is an important pathway for freshwater. The southward volume flux of seawater via this route is estimated to be between 0.57 and $0.8 \mathrm{~Sv}\left(\mathrm{~Sv}=10^{6} \mathrm{~m}^{3} \mathrm{~s}^{-1}\right.$ ) (Sadler, 1976; Münchow et al., 2006; Münchow and Melling, 2008), under a variety of caveats concerning the scope of measurements, part of instrumented cross section and averaging period. Estimates for volume flux through the complete CAA vary around 1-2 Sv (Rudels, 1986, 2011; Fissel et al., 1988). Curry et al. (2011) estimate a southward volume flux in Davis Strait of $2.3 \pm 0.7 \mathrm{~Sv}$. For comparison, the net yearly southward volume transport through Fram Strait is thought to be $2 \pm 2$ to $4 \pm 2$ Sv (Schauer et al., 2004). Fram Strait exports about 64-80 mSv of freshwater in solid form and 32-95 mSv in liquid form (Aagaard and Carmack, 1989; Kwok and Rothrock, 1999; Serreze et al., 2006; Dickson et al., 2007; Holfort et al., 2008; Rabe et al., 2009; de Steur et al., 2009). The freshwater export through the CAA is not well known. Both observations and models have serious shortcomings. Estimates for the outflow in liquid form range between 30 and $100 \mathrm{mSv}$ (Rudels, 1986; Aagaard and Carmack, 1989; Steele et al., 1996; Serreze et al., 2006), with recent estimates in Davis Strait reaching $116 \pm 41 \mathrm{mSv}$ (Curry et al., 2011). In comparison, only about $5 \mathrm{mSv}$ is exported in solid form (Serreze et al., 2006). The ice flux through Nares Strait has been estimated as $4 \mathrm{mSv}$ and $8 \mathrm{mSv}$ (Kwok, 2005; Kwok et al., 2010). While Fram Strait exports about the same amount of freshwater in liquid and solid form, the CAA moves more freshwater in liquid form than as ice.

Ice conditions in Nares Strait alternate between two states. Typically, ice starts moving through the strait between June and August, and this continues until laud-fast ice (hereafter called fast-ice) forms again sometime between November and March. Fast-ice persists for the remainder of the year. The transition between mobile-ice and fast-ice conditions is precipitated by the formation of an ice bridge across Smith Sound (Dunbar, 1973; Melling, 2000; Barber et al., 2001; Kwok, 2005; Dumont et al., 2009; Kwok et al., 2010). Such a bridge, anchored to the coasts of Greenland and Ellesmere Island, can resist the forces of tidal current and wind for many months (Samelson et al., 2006; Dumont et al., 2009). Ice mobility can be embodied in an ice-state index (Münchow and Melling, 2008) that distinguishes intervals of fast-ice from mobile ice. Table 1 lists the approximate dates of transition and lengths of the three fast-ice and four mobile-ice seasons from 2003 to 2006. Transition dates are based on measurements of the speed of ice drift by upward-looking Doppler sonar. 
Table 1. Ice index: start date, end date, and length of each ice season. Mobile-ice occurs in late summer, fall, and early winter, while fast-ice occurs in late winter, spring, and early summer, according to the ice index defined by Münchow and Melling (2008).

\begin{tabular}{lccc}
\hline Season & Start date & End Date & Length (days) \\
\hline Mobile-ice 2003 & $08 / 04 / 2003^{*}$ & $03 / 11 / 2004$ & 220 \\
Fast-ice 2003-2004 & $03 / 11 / 2004$ & $06 / 17 / 2004$ & 97 \\
Mobile-ice 2004 & $06 / 17 / 2004$ & $12 / 18 / 2004$ & 184 \\
Fast-ice 2004-2005 & $12 / 18 / 2004$ & $07 / 02 / 2005$ & 196 \\
Mobile-ice 2005 & $07 / 02 / 2005$ & $01 / 13 / 2006$ & 195 \\
Fast-ice 2005-2006 & $01 / 13 / 2006$ & $06 / 15 / 2006$ & 153 \\
Mobile-ice 2006 & $06 / 15 / 2006$ & $08 / 13 / 2006^{\dagger}$ & 59 \\
\hline
\end{tabular}

*Time of mooring deployment.

$\dagger$ Time of mooring recovery.

This study extends the analysis of Münchow and Melling (2008) and Rabe et al. (2010) by considering variations in geostrophic flow structure in space and time. Water mass descriptions within Nares Strait and to the north and south of the sills can be found in Münchow et al. (2006), Rabe et al. (2010) and Münchow et al. (2011). After discussing geostrophic volume and freshwater fluxes we diagnose the forcing of through-flow by along-channel wind and pressure differences.

\section{Study area and data}

The CAA defines a network of straits that connects the Arctic Ocean to the North Atlantic. Fluxes through these gateways are an important part of the Arctic Ocean freshwater budget. This study is focused on Nares Strait, which separates Ellesmere Island from Greenland. An array of oceanographic moorings carrying conductivity-temperature (CT) recorders (at 30-, 80-, 130-, and 200-m and seabed depths) and 75-kHz ADCPs (at the seabed) was deployed in 2003 at $80.5^{\circ} \mathrm{N}$. Here, about $100 \mathrm{~km}$ north of the 230-m deep sill in Kane Basin (Fig. 1), the strait is about $38 \mathrm{~km}$ wide and $400 \mathrm{~m}$ deep. CT moorings were spaced about $5 \mathrm{~km}$ apart (Table 2).

Figure 2 shows the nominal position of all instruments within the cross section. The naming convention starts with KS01 on the Ellesmere Island side, increasing to KS14 on the Greenland side. KSO2 will refer to the location of geostrophic velocity estimated from CT data collected at KS01 and KS03, while KS10 refers to the same estimated from data at KS09 and KS13, and so on. The phrase "geostrophic velocity" is used throughout to denote the speed of the geostrophic flow along the channel to the south-west. Bottommounted mooring locations are indicated as KS02a, KS10a, and so on. Bottom-pressure recorders were deployed at two sheltered coastal sites, Foulke Fjord and Alexandra Fjord, about $250 \mathrm{~km}$ to the south. Details of the CT and ADCP moorings are described in Rabe et al. (2010) and Münchow and Melling (2008), respectively. Overall 28 CT instruments 
Table 2. Location and details of the recovered moorings containing $\mathrm{CT}$ instruments and pressure sensors (ps).

\begin{tabular}{llcccc}
\hline Name & Type & Latitude & Longitude & $\begin{array}{c}\text { Record Length } \\
\text { (days) }\end{array}$ & Nominal Depth \\
\hline KS01 & CT & $8033.470 \mathrm{~N}$ & $6854.456 \mathrm{~W}$ & 1108 & $30^{*} 80130200^{*}$ \\
KS02a & CT & $8033.228 \mathrm{~N}$ & $6852.466 \mathrm{~W}$ & 1103 & 302 \\
KS03 & CT & $8032.697 \mathrm{~N}$ & $6847.307 \mathrm{~W}$ & 1104 & $29^{*} 79^{*} 129199^{* \dagger}$ \\
KS05 & CT & $8031.139 \mathrm{~N}$ & $6834.808 \mathrm{~W}$ & 1104 & $27^{*} 77127197^{*}$ \\
KS07 & CT & $8029.372 \mathrm{~N}$ & $6819.455 \mathrm{~W}$ & 1105 & $32^{*} 82132202^{*}$ \\
KS09 & CT & $8027.349 \mathrm{~N}$ & $6803.839 \mathrm{~W}$ & 1104 & $38^{*} 88138208^{*}$ \\
KS10a & CT & $8026.326 \mathrm{~N}$ & $6755.779 \mathrm{~W}$ & 1105 & 299 \\
KS12a & CT & $8024.553 \mathrm{~N}$ & $6740.255 \mathrm{~W}$ & 1104 & 263 \\
KS13 & CT & $8023.801 \mathrm{~N}$ & $6734.575 \mathrm{~W}$ & 1106 & $32^{*} 82132202^{*}$ \\
KS14a & CT & $8023.305 \mathrm{~N}$ & $6726.751 \mathrm{~W}$ & 1103 & 157 \\
P1 Foulke & Pressure & $7818.000 \mathrm{~N}$ & $7234.200 \mathrm{~W}$ & 1116 & 24 \\
P2 Alexandra & Pressure & $7854.600 \mathrm{~N}$ & $7548.000 \mathrm{~W}$ & 1099 & 23 \\
P Alert & Pressure & $8229.512 \mathrm{~N}$ & $6219.038 \mathrm{~W}$ & ongoing & Height above \\
& & & & & chart datum: $3 \mathrm{~m}$ \\
\hline
\end{tabular}

*ps.

$\dagger$ ps malfunction after 500 days.

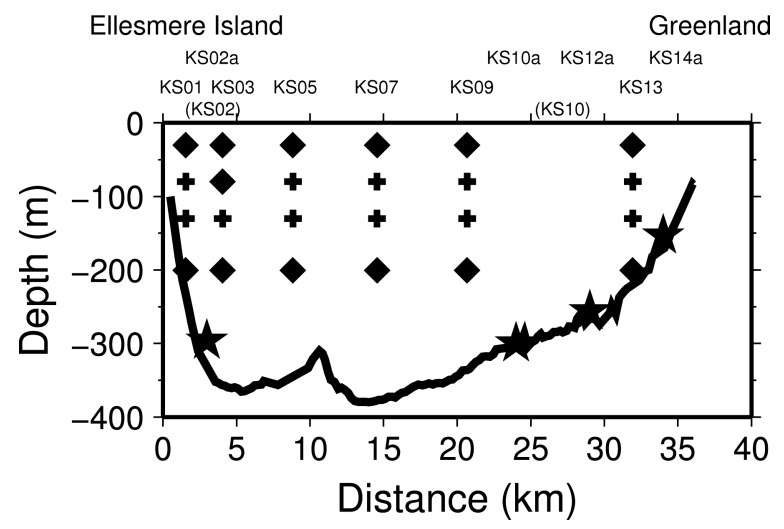

Figure 2. Position of recovered instruments. There were six string moorings, each containing four $\mathrm{CT}$ instruments, and four bottom-mounted moorings comprising an ADCP and CT instrument. Ellesmere Island (E.I.) is on the left (west) and Greenland is on the right (east). CT instruments were deployed at nominal 30-, 80-, 130- and 200-m depths. Diamonds denote instruments with pressure sensors and crosses those without. Stars denote bottom-mounted moorings. Mooring numbering is in sequence starting on the Ellesmere Island side, with CT moorings as odd numbers and bottommounted moorings as even numbers with an "a" at the end. (KSO2) is the middle point of the geostrophic velocity estimated from data at $\mathrm{KS} 01$ and $\mathrm{KSO3}$; (KS10) is the middle point of the geostrophic velocity estimated from data at KS09 and KS13; KS04, KS06, and KS08 are in between accordingly. Data from ADCP mooring KS10a, 24 km from E.I., was used for the reference-level velocity. 


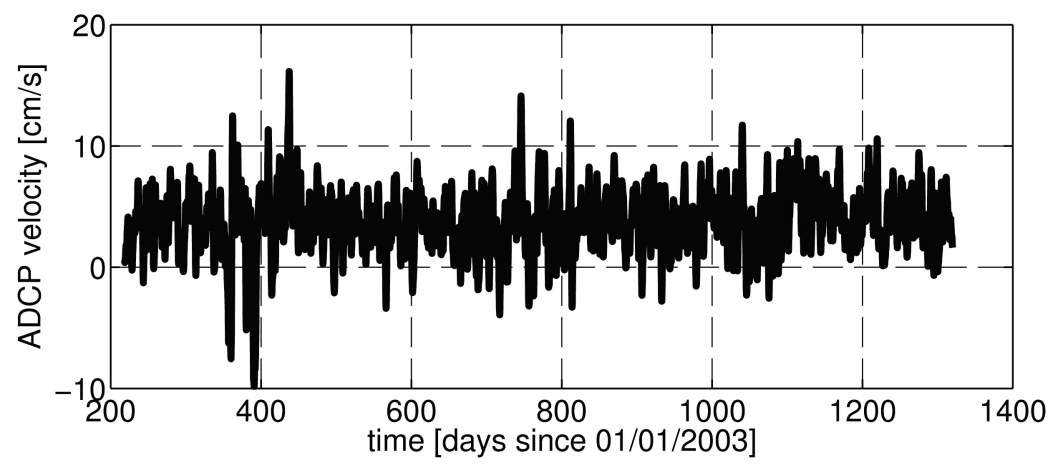

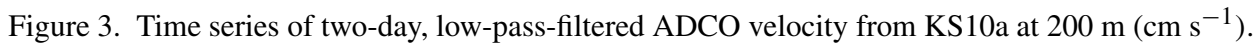
Positive velocities are to the south. This time series is representative of velocities at $200 \mathrm{~m}$ across the whole strait; the correlation between KS02a and KS10a is around 0.5 on short timescales. This time series is used to supply a reference-level velocity for the geostrophic velocity calculations.

(SBE37s) were recovered in 2006 with complete three-year records. We estimate that fouling of the SBE37's conductivity cell causes drift in its calibration, creating a spurious trend to lower salinity by about 0.02 psu per year (Appendix A). For water of 34.6 salinity (at the seabed), this biases freshwater flux by $+30 \%$ over three years; for water of 32.5 salinity (near surface) the bias error after three years is only $+3 \%$. Overall, the drift is an insignificant contributor to overall uncertainty.

The top $200 \mathrm{~m}$ of our CT mooring strings were deliberately fitted with minimal buoyancy, so that the strings would be pulled downward by strong current to avoid becoming snagged by moving ice. We have taken advantage of this vertical motion at tidal frequency to enhance the nominal 50-m vertical resolution of salinity and density fields on longer time scales. Appendix B describes the multiple regression model that was used to derive depth-time fields of temperature and salinity at three-hour time steps. A Hanning low-pass filter with a window width of 48 hours was applied to both salinity and temperature before calculating the density field. This density field was then used to calculate, using the thermal wind equation, the geostrophic velocity, referenced to the similarly smoothed, (with a Hanning low-pass filter with a window width of 48 hours), current velocity measured at 200-m depth by ADCP at site KS10a (Fig. 3). The time series at KS10a is representative of velocities at $200 \mathrm{~m}$ across the whole strait. On short timescales the correlation between KS02a and $\mathrm{KS} 10 \mathrm{a}$ is around 0.5 . The time series of current velocity is also used to supply a reference level velocity for the geostrophic velocity calculations.

It is possible to generate credible estimates of volume and freshwater fluxes through Nares Strait using these cross-sectional fields of geostrophic velocity and salinity that resolve the internal Rossby scale. The top $30 \mathrm{~m}$ are not included; neither is freshwater carried by the sea ice. The horizontal and vertical domain of this $30-\mathrm{km}$ wide array of measurements, (hereafter "measured section"), accounts for $74 \%$ of the strait cross-sectional area above 
$200 \mathrm{~m}$, or $48 \%$ of the total cross-sectional area. Neglect of the uppermost $30 \mathrm{~m}$ will have a strong impact on both fluxes with drifting ice, because the flow speed and the freshwater fraction both increase toward the surface. The impact is less with fast-ice because the flow speed decreases to zero at the surface. The along- and across-channel directions are defined as $x$ and $y$-coordinates, with $u$ as the along-channel velocity (positive southward) and $v$ the across-channel velocity (positive eastward).

Geostrophic volume flux is defined as

$$
q=\int_{A} u_{g}(y, z, t) d A
$$

where $u_{g}(y, z, t)$ is the along-channel geostrophic velocity normal to area $A$ in the $(y, z)$ plane, and $d A$ is the area representative of each single data point, given by $1-\mathrm{m}$ distance in the vertical multiplied by the horizontal distance between the mooring midpoints.

Geostrophic freshwater flux is defined as

$$
F=\int_{A} u_{g}(y, z, t)\left(1-\frac{S(y, z, t)}{S_{0}}\right) d A
$$

where $S(y, z, t)$ is the salinity, $S_{0}$ is the customary reference salinity for the Arctic Ocean (34.8 psu: Aagaard and Carmack (1989)), and $\left(1-\frac{S(y, z, t)}{S_{0}}\right)$ is the salinity anomaly $F_{a}(y, z, t)$. Note that because the integrals are evaluated using two-day filtered data and we reconstructed the variability associated only with the background field, tidal contributions to the freshwater flux are therefore eliminated.

Uncertainties in the flux estimates are given with a $95 \%$ confidence limit:

$$
1.96 * s t d * \sqrt{\frac{2}{n}},
$$

with $n=\frac{T}{T_{D}}$ the degrees of freedom (dof), T the record length (1101 days for the full record), and $T_{D}$ the decorrelation time scale of the time series of 138 hours (195 hours) for the volume (freshwater) flux, (equal to the integral of the autocorrelation function to the first zero crossing; Kundu and Allen, 1976).

The three-year time series of anomalies in along-channel pressure difference was estimated by Münchow and Melling (2008) and is expressed dynamically in terms of hydrostatic pressure anomalies at the bottom. Münchow and Melling (2008) used data from two bottom-pressure sensors in Smith Sound at the southern entrance to Nares Strait, (mean pressures removed) and sea-level data from a tide gauge in Alert $300 \mathrm{~km}$ to the north (atmospheric pressure added and mean removed). Atmospheric pressure systems impact both along-channel pressure difference and local wind. No direct wind observations exist from the period 2003-2006. Hence we use modeled 10-m wind (Samelson and Barbour, 2008) to estimate the local wind stress forcing. 
(a)
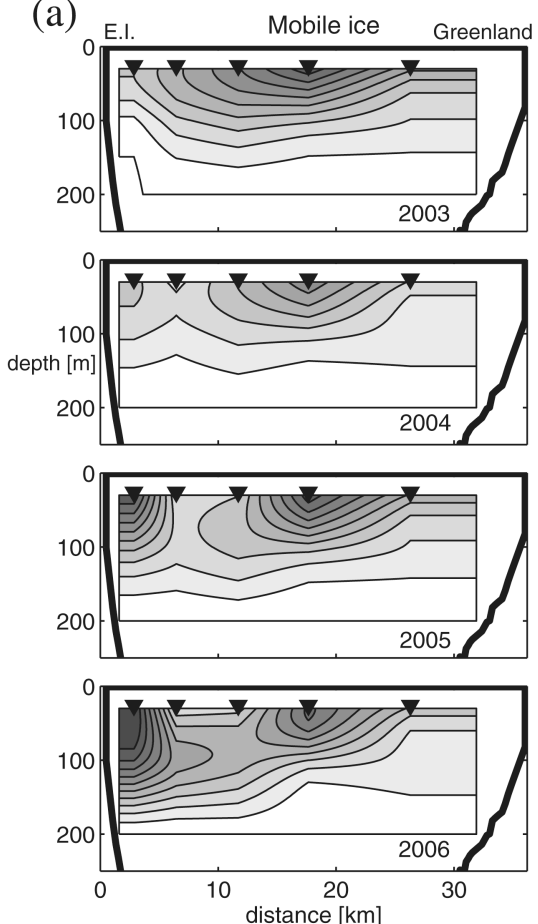

(b)
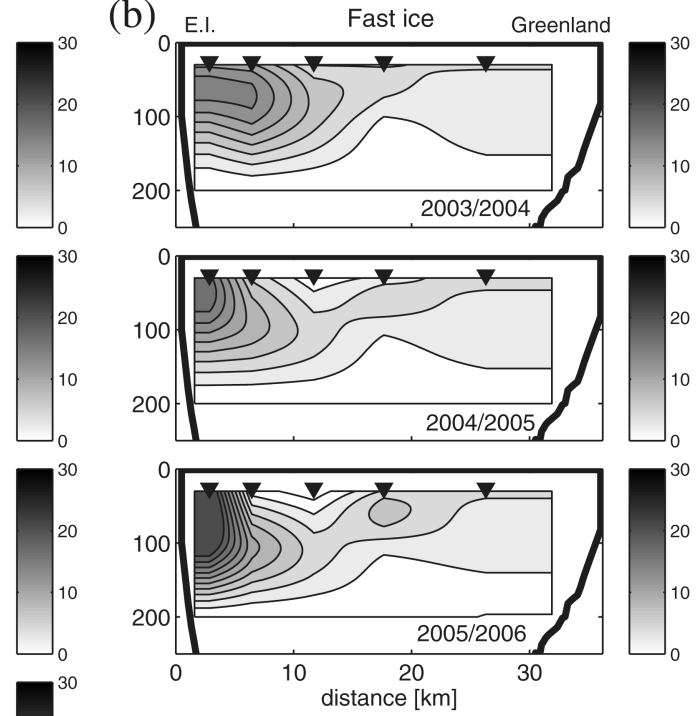

Figure 4. Sections of mean geostrophic velocity at seasonal timescales during each (a) mobile-ice and (b) fast-ice season. Zero geostrophic velocity is denoted in white, and positive velocities are to the south $\left[\mathrm{cm} \mathrm{s}^{-1}\right]$. Each black triangle denotes the horizontal position of a midpoint between two density profiles; the vertical resolution is $1 \mathrm{~m}$. The contour interval is $2 \mathrm{~cm} \mathrm{~s}^{-1}$.

\section{Salinity and geostrophic velocity variability on sub-tidal time scales}

In this section we will analyze the temporal variability of geostrophic velocity over timescales from seasonal (the ice-state variability time scale), through interannual, to multiyear variations. Salinity is evaluated on internannual and multiyear time scales.

\section{a. Variation of geostrophic velocity with ice state}

This section examines changes in geostrophic velocity over the three years within the context of fast-ice and mobile-ice seasons. Figure 4 shows geostrophic velocity sections for all observed intervals of the annual ice-cover cycle. The 2006 phase of mobile ice was cut short by recovery of the moorings.

During the 2003 mobile-ice season a main shallow core close to the surface was observed in the middle of the strait with geostrophic velocities of $0.25 \mathrm{~m} \mathrm{~s}^{-1}$. This core also emerged from empirical orthogonal function (EOF) analysis of the salinity data (Rabe et al., 2010). 
The strong geostrophic shear that created the strongest near-surface current at mid-channel with mobile-ice conditions was linked to a sharp horizontal gradient in salinity at this location. The front may mark the eastern boundary of melt-water linked to the ice stream that occupies the western half of the channel in summer. During the 2004 mobile-ice season, the geostrophic velocity in the core was weaker by 30\%, but returned to strength in 2005 . Velocities were more concentrated in the middle of the strait (between $\mathrm{km} 12$ and 25) in 2005 relative to 2003 ( $\mathrm{km} 5$ to 25). Under mobile ice in 2005 and 2006, a second stream of flow appeared near the Ellesmere Island side. Our data reveal a transition from a single jet in the center of the channel to a two-jet structure with an emerging coastal current adjacent to Ellesmere Island. This second velocity core is similar to that under fast-ice, although its maximum flow is near $30 \mathrm{~m}$, rather than at 40- to 60-m depth. The lack of a core in 2003 may be linked to the almost complete absence of ice in Kennedy Channel that year; winds were largely from the south at that time as well. In contrast, close pack ice filled the western half of the channel during the summers of 2005 and 2006.

During fast-ice seasons a core of southward flow existed at 40- to 60-m depth within $7 \mathrm{~km}$ of Ellesmere Island. Its time-mean peak speed was $0.18 \mathrm{~m} \mathrm{~s}^{-1}, 0.22 \mathrm{~m} \mathrm{~s}^{-1}$ and $0.32 \mathrm{~m} \mathrm{~s}^{-1}$ during the 2003-2004, 2004-2005 and 2005-2006 fast-ice seasons. Flow was relatively weak throughout the remainder of the section.

\section{b. Interannual variability}

i. Salinity. Figures 5 and 6 show salinity versus depth and time at KS01, close to Ellesmere Island, and KS13, close to Greenland, respectively. At both locations, high-frequency fluctuations in salinity occurred at all depths, but their amplitude was much stronger during intervals with mobile-ice than during those with fast-ice. Generally, the vertical excursions of isohalines were greater on the western side of the strait than on the eastern side. The salinity at $30 \mathrm{~m}$ was generally lower under mobile-ice than under fast-ice, although this may merely reflect the likelihood that ice will be mobile during the melting season. The surface layer was fresher on the western side, consistent with Rabe et al. (2010). Downwelling on the western side deepened the surface layer and provided a glimpse of seawater properties in the upper $30 \mathrm{~m}$ of the ocean, where we were not able to make measurements. There is evidence of saltier water at depth on the eastern side, particularly during fast-ice conditions.

Figure 7 shows along-channel wind. There is a clear correlation between freshwater incursions during mobile-ice seasons and wind events. Two particularly strong southward wind events with speed of up to $20 \mathrm{~m} \mathrm{~s}^{-1}$ occurred in January 2004, coinciding with freshwater incursions that reached $180 \mathrm{~m}$ at KS01. Peaks in wind in October 2003, November 2004 and December 2005 were all accompanied by similar freshwater incursions. During the fast-ice season, the ocean was isolated from wind stress and much less responsive to the occurrence of strong winds within the strait. Comparing the figures for KS01 and KS13, we see that wind causing downwelling and negative salinity anomalies on the western side 

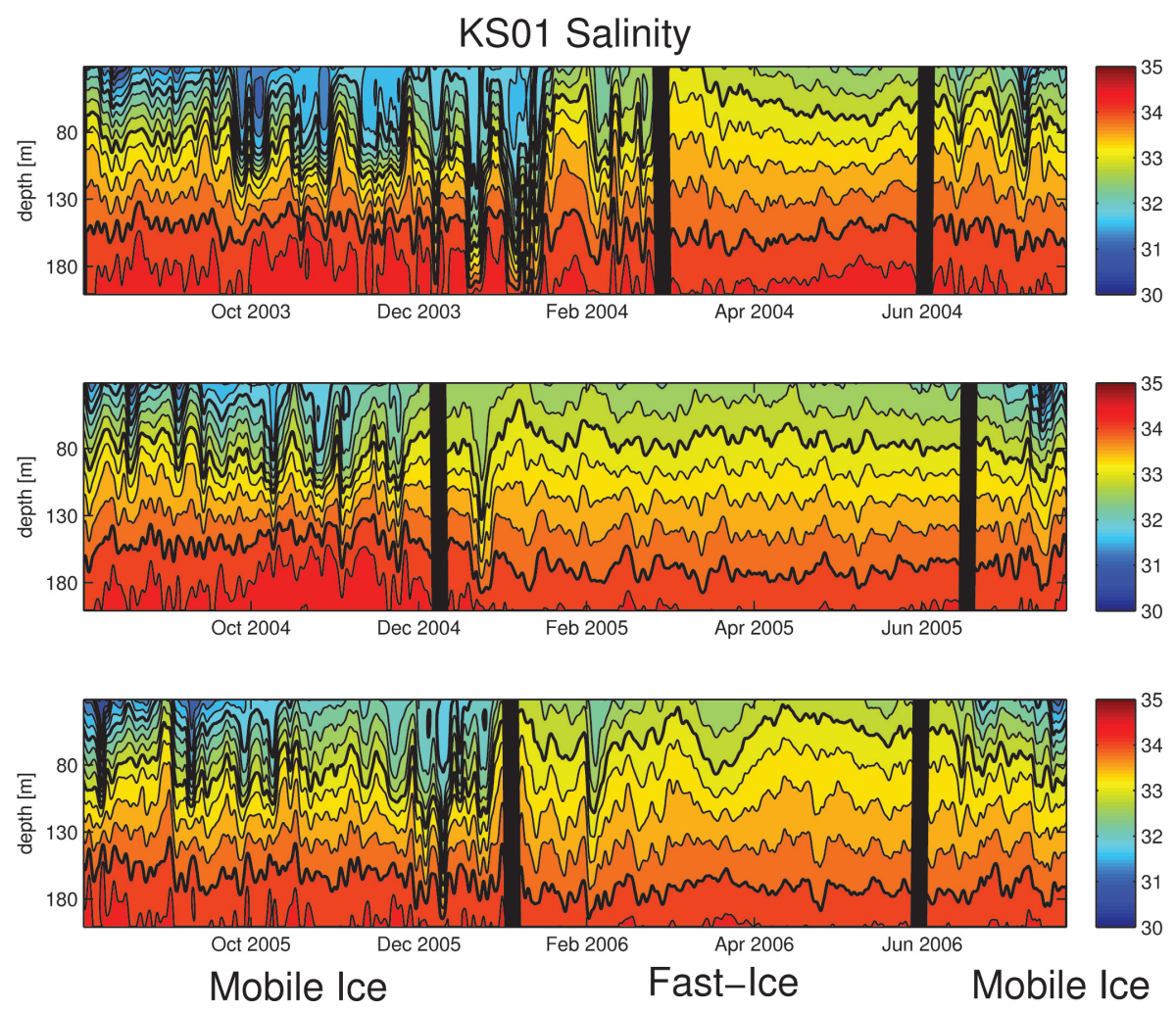

Figure 5. Hovmöller diagram for salinity as a function of time and depth at KS01. Each panel represents one year from August to August for 30 to $200 \mathrm{~m}$. Vertical black lines represent changes in the ice index, with the left and right side of each panel representing mobile-ice seasons and the middle part of each panel representing fast-ice seasons. The contour interval is $0.25 \mathrm{psu}$, with the thicker isohalines plotted at 34.0, 33.0, 32.0, 31.0 and 30.0 psu.

of the channel resulted in upwelling and positive salinity anomalies on the eastern side, and vice versa.

ii. Geostrophic velocity. Figure 8 shows geostrophic velocity estimated at KS02, KS08 and KS10; the along-channel wind; and the ice index. A 30-day low-pass filter was applied to all data to emphasize longer-than-monthly variability. Close to Ellesmere Island (KS02) a maximum in geostrophic velocity in the top $100 \mathrm{~m}$ was most pronounced during fast-ice periods and was much stronger in 2006 than in earlier years. During the fast-ice periods there is a concentration of the southward flow close to Ellesmere Island, rather than it being spread out over more of the strait. One possible cause is the Ekman layer associated with the lid of the fast-ice, which might modify the baroclinicity of the upper ocean and thereby change the cross-sectional structure of the flow. Work is ongoing to understand the structure 

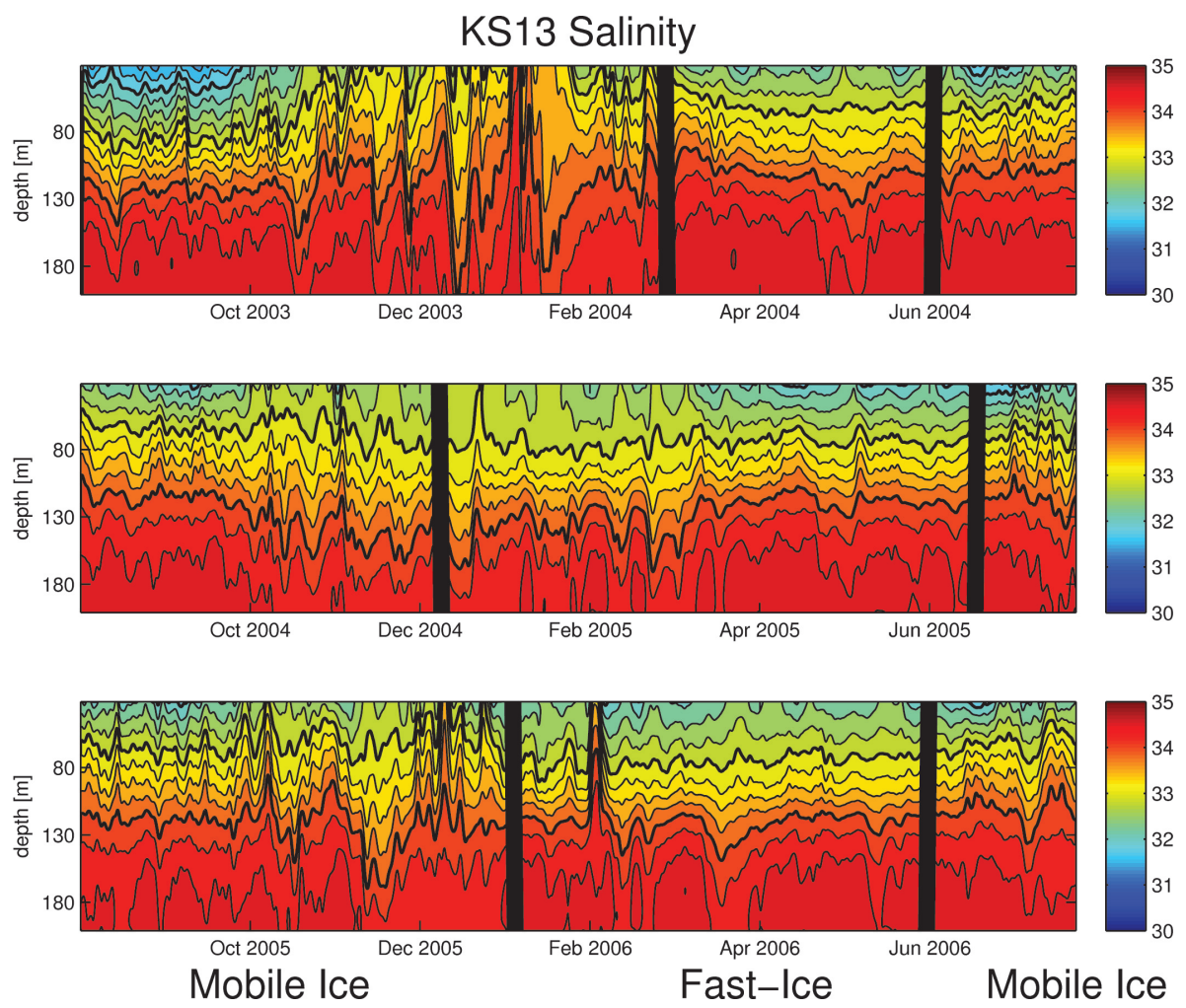

Figure 6. Hovmöller diagram for salinity as a function of time and depth at KS13. Each panel represent one year from August to August for 30 to $200 \mathrm{~m}$. Vertical black lines represent changes in the ice index, with the left and right side of each panel representing mobile-ice seasons and the middle part of each panel representing fast-ice seasons. The contour interval is $0.25 \mathrm{psu}$, with thicker isohalines plotted at 34.0, 33.0, 32.0, 31.0 and 30.0 psu.

of the flow and the reasons for the intensified flow close to Ellesmere Island in more detail. Two anomalies with northward geostrophic flow occurred in November/December 2003 between 80 and $150 \mathrm{~m}$, each lasting about one month. In the middle of the strait (KS08), flow was strongest near the surface and during intervals with mobile ice. Flow was strong at $\mathrm{KS} 08$ when weak at $\mathrm{KS} 02$, and vice versa. The fastest flow at $\mathrm{KS} 08\left(0.48 \mathrm{~m} \mathrm{~s}^{-1}\right)$ occurred in January 2004, coincident with maximum southward wind. Flow velocity was generally lower on the eastern side of the strait (KS10) than further west. The two strongest events (January 2004 and December 2005) accompanied strong wind events.

Traditional ways to present variability using monthly means and annual cycles are not always appropriate in Nares Strait, because intra-annual variations are controlled by the change in the state of the ice cover (fast or mobile), which may be associated loosely with the winter and summer seasons, respectively. 

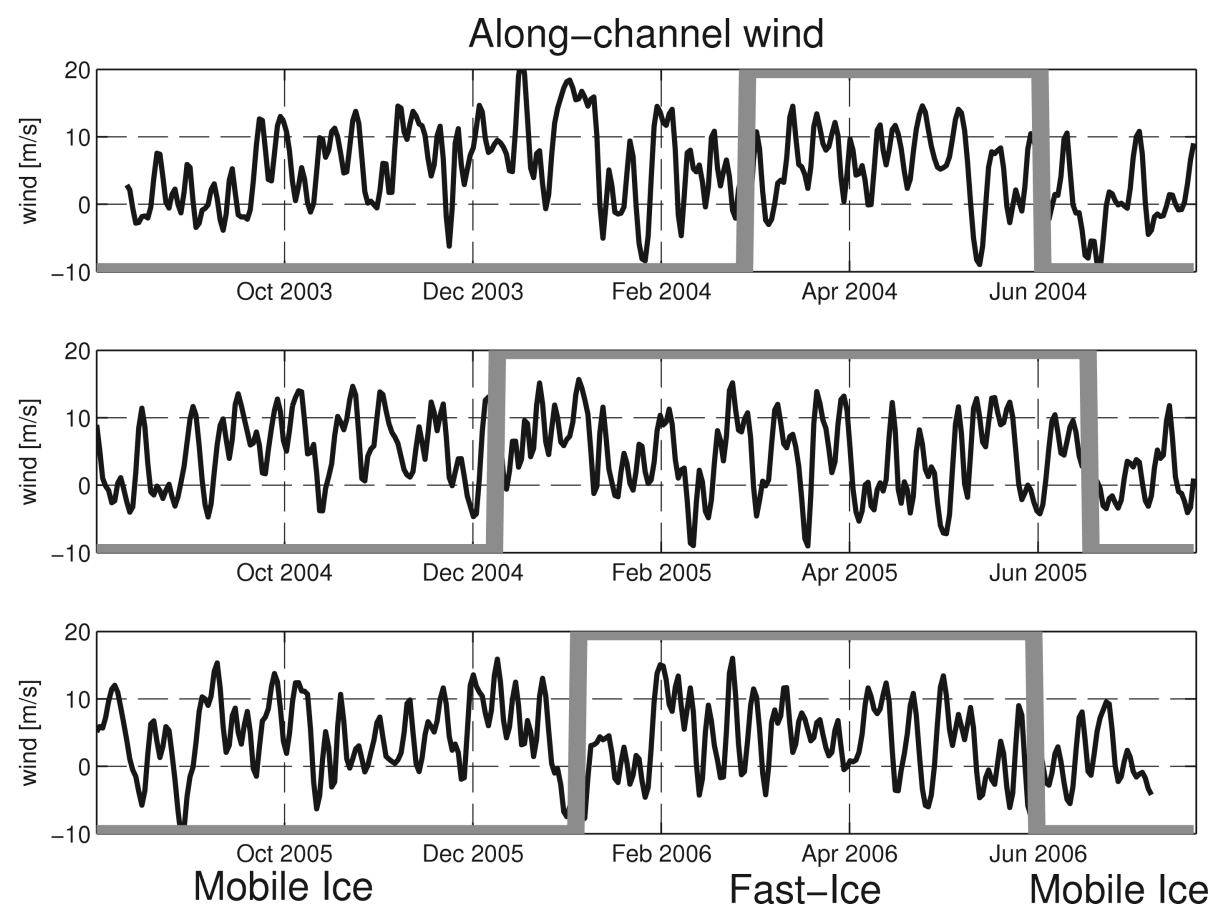

Figure 7. Timeseries of daily values of along-channel wind speed $\left(\mathrm{m} \mathrm{s}^{-1}\right)$ at $10 \mathrm{~m}$ from the atmospheric model by Samelson and Barbour (2008), after Münchow and Melling (2008). Positive velocities denote wind to the south Each panel represents one year from August to August. The ice index is shown in grey, with negative values for mobile-ice seasons and positive values for fast-ice seasons (the middle part of each panel represents fast-ice seasons, while the left and right side of each panel represents mobile-ice seasons).

Figures 9 and 10 present a more-detailed view of geostrophic flow fluctuations through the strait, displayed using time series that have been filtered with a cut-off period of two days. The two sites chosen for display (KS02, KS08) are centered within the sub-surface jet against the Ellesmere shore under fast-ice, and the surface stream in the center of the strait with mobile ice (Rabe et al., 2010).

Under fast-ice, the sub-surface maximum at KSO2 reached $0.30 \mathrm{~m} \mathrm{~s}^{-1}$ during 2003$2004,0.35 \mathrm{~m} \mathrm{~s}^{-1}$ in 2004-2005, and $0.50 \mathrm{~m} \mathrm{~s}^{-1}$ in 2005-2006, with maximum velocities extending from 30 to $130 \mathrm{~m}$. At KS08, $17 \mathrm{~km}$ from Ellesmere Island, flow under fast-ice was only about $0.05 \mathrm{~m} \mathrm{~s}^{-1}$, with occasional subsurface bursts to $0.15 \mathrm{~m} \mathrm{~s}^{-1}$ at about $50 \mathrm{~m}$. However, there was one event, in February 2006, wherein flow reached $0.40 \mathrm{~m} \mathrm{~s}^{-1}$ southward between 30 and $130 \mathrm{~m}$.

With mobile-ice, at KS02 the geostrophic flow was concentrated in the top $80 \mathrm{~m}$ and predominantly southward at 0.05 to $0.25 \mathrm{~m} \mathrm{~s}^{-1}$. Overall flow was stronger during the 2005 mobile-ice season, reaching $0.55 \mathrm{~m} \mathrm{~s}^{-1}$. However, the maximum southward short-term pulse 
KS02 Geostrophic Velocity

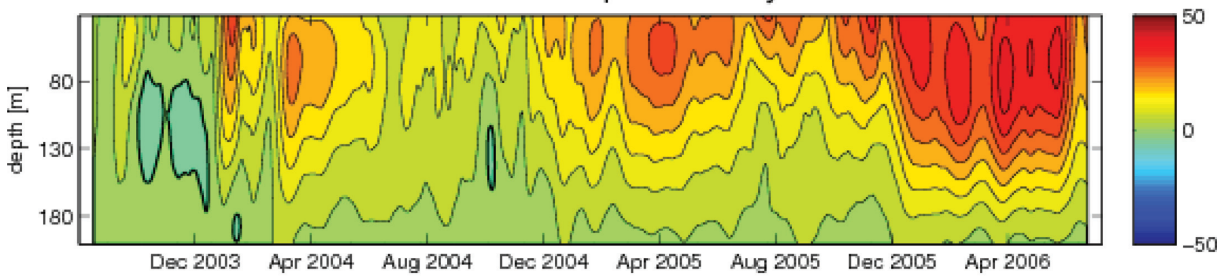

KS08 Geostrophic Velocity

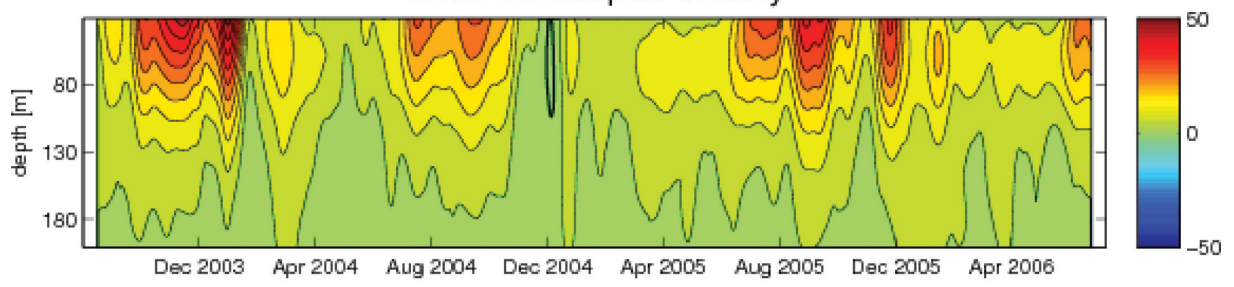

KS10 Geostrophic Velocity

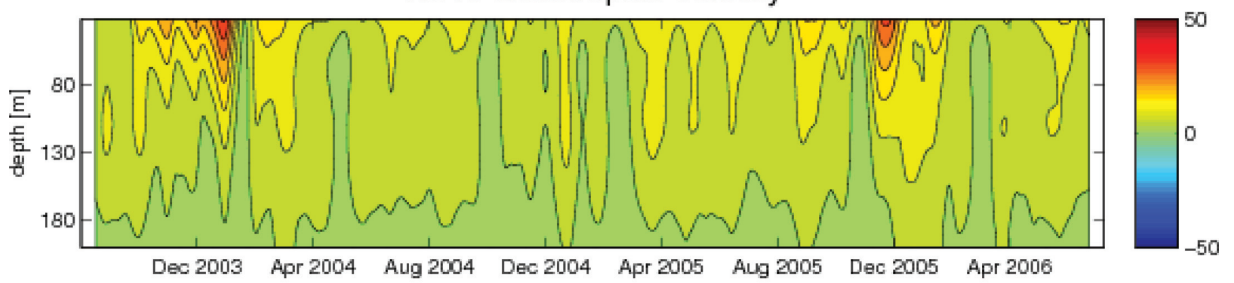

Along-channel wind

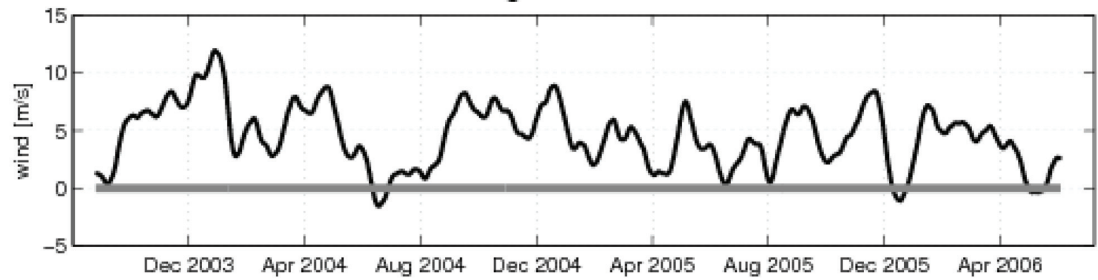

Ice index

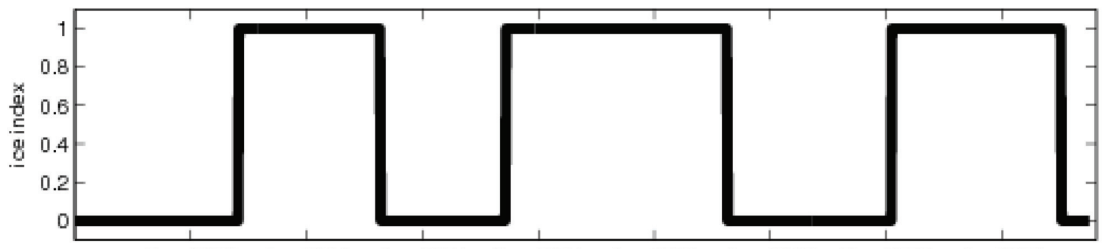

Dec 2003 Apr 2004 Aug 2004 Dec 2004 Apr 2005 Aug 2005 Dec 2005 Apr 2006

Figure 8. Hovmöller diagrams for 30-day low-pass filtered absolute geostrophic velocity as a function of time and depth at KS02, KS08 and KS10. Positive geostrophic velocities are to the south ( $\mathrm{cm} \mathrm{s}^{-1}$ ). Each panel represents the three-year record from August 2003 to August 2006 for 30 to $200 \mathrm{~m}$. The zero contour is marked by a thicker line, and blue colors indicate negative velocity (i.e., to the north). The contour interval is $0.05 \mathrm{~cm} \mathrm{~s}^{-1}$. The 30-day, low-pass-filtered, along-channel wind is also plotted (zero line in grey) as well as the ice index, with zero representing mobile-ice seasons and one fast-ice season. 

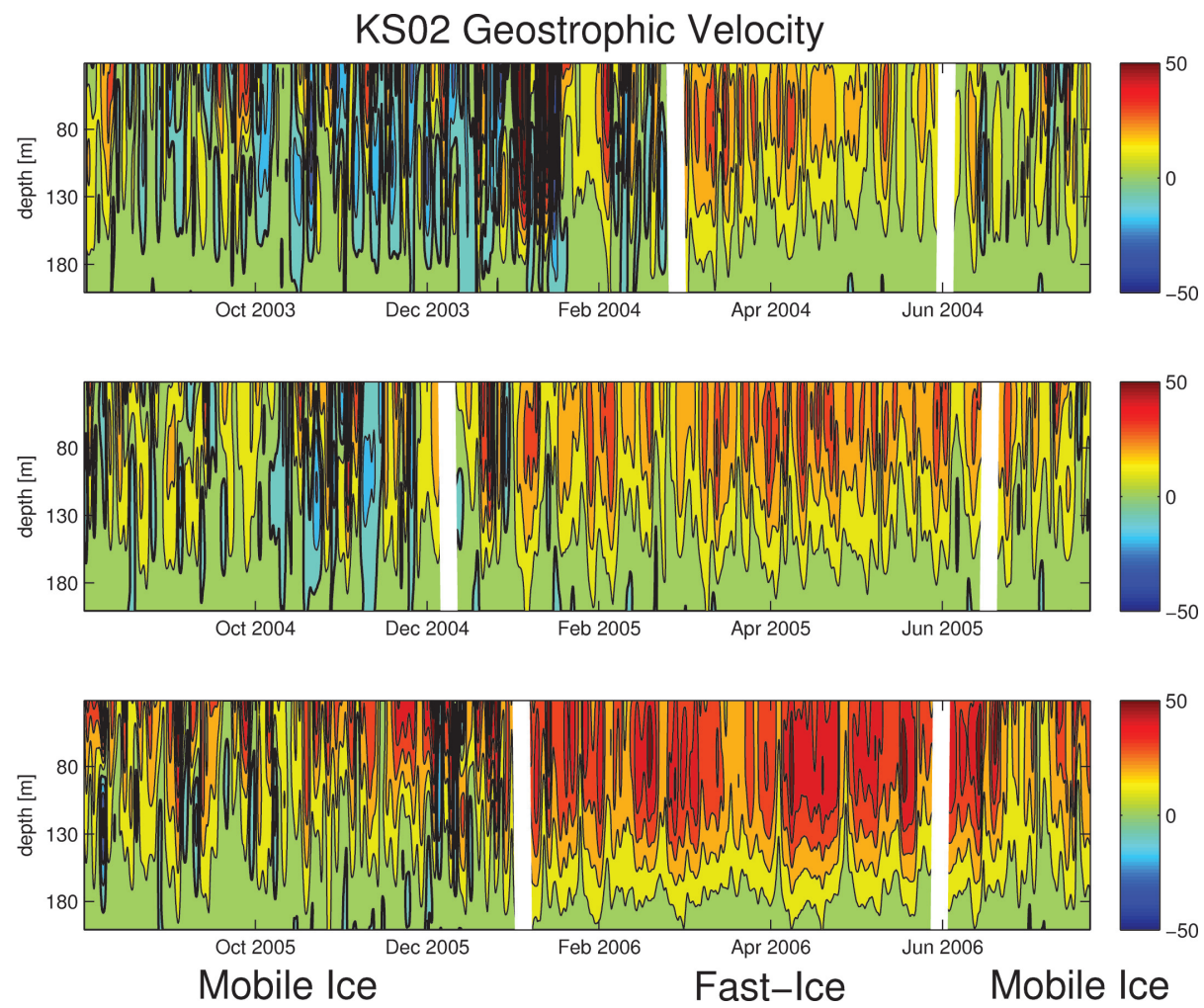

Figure 9. Hovmöller diagram for absolute geostrophic velocity as a function of time and depth at KS02. Positive geostrophic velocities are to the south $\left(\mathrm{cm} \mathrm{s}^{-1}\right)$. Each panel represents one year from August to August. Vertical white lines represent change in the ice index, with the left and right side of each panel representing mobile-ice seasons and the middle part of each panel representing fast-ice seasons. The zero contour is marked by a thicker black line, and blue colors indicate negative velocity (i.e., to the north). The contour interval is $10 \mathrm{~cm} \mathrm{~s}^{-1}$.

of geostrophic flow of $0.95 \mathrm{~m} \mathrm{~s}^{-1}$ occurred during 2003. Northward flow, usually lasting a few days, was common during 2003 but occurred only about 10 times in subsequent years. With mobile-ice at KS08, pulses of surface-intensified flow reached $0.80 \mathrm{~m} \mathrm{~s}^{-1}$ during 2003 (30 to $100 \mathrm{~m}$ ), $0.30 \mathrm{~m} \mathrm{~s}^{-1}$ in 2004 (only down to $80 \mathrm{~m}$ ), and $0.50 \mathrm{~m} \mathrm{~s}^{-1}$ in 2005 (down to $100 \mathrm{~m}$ ). Only a few events with the northward geostrophic flow were observed at KS08, each one lasting a few days. Maximum geostrophic velocity occurred in the season of mobile ice.

Further east at KS10 (not shown), the geostrophic flow was generally southward, with pulses, each lasting a few days, that were weaker here than in the middle of the strait. Occasional northward flows reached $0.10 \mathrm{~m} \mathrm{~s}^{-1}$ throughout the water column (30 to $200 \mathrm{~m}$ ) seven times in the three years. 

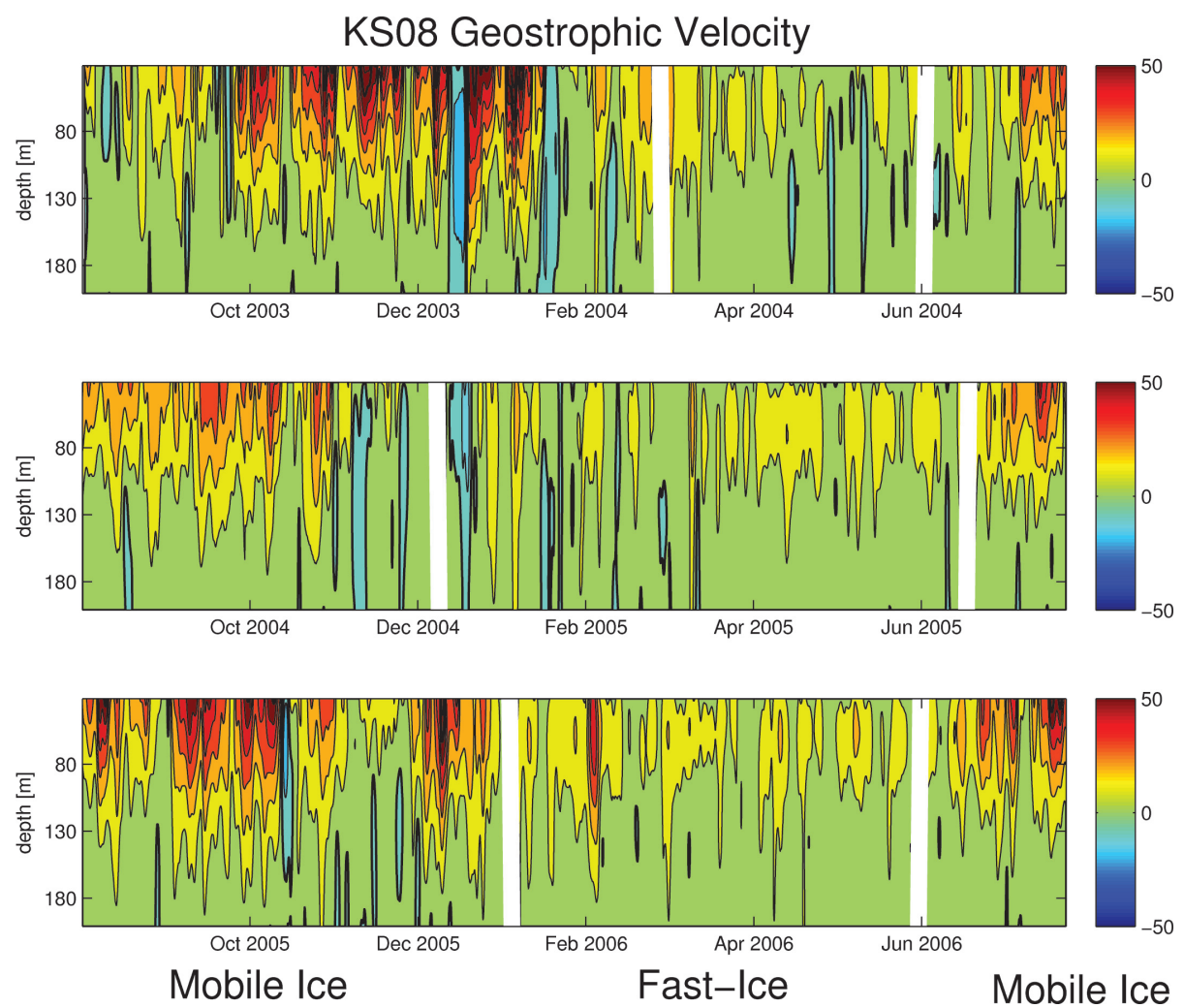

Figure 10. Hovmöller diagram for absolute geostrophic velocity as a function of time and depth at KS08. Positive geostrophic velocities are to the south in $\mathrm{cm} \mathrm{s}^{-1}$. Each panel represents one year from August to August for 30 to $200 \mathrm{~m}$. Vertical white lines represent changes in the ice index, with the left and right side of each panel representing mobile-ice seasons and the middle part of each panel representing fast-ice seasons. The zero contour is marked by a thicker black line, and blue colors indicate negative velocity (i.e., to the north). The contour interval is $10 \mathrm{~cm} \mathrm{~s}^{-1}$.

\section{c. Multiyear changes of salinity and geostrophic velocity over the observation period}

The salinity and geostrophic velocity records contain statistically significant linear trends, indicating temporal variability at scales longer than three years. Appendix A demonstrates that the changes do not result entirely from sensor drift (which is smaller than 0.02 psu per year), and hence represent a physical change in salinity, temperature and geostrophic velocity patterns in Nares Strait.

i. Salinity. Figure 11a shows the change in salinity during the three years of observation from fitting a linear trend line. Surface waters near Ellesmere Island (KS01, KS03) became saltier at $50 \mathrm{~m}$ between 2003 and 2006, whereas waters below $120 \mathrm{~m}$ depth became fresher. This is consistent with the significant freshening trend in the bottom waters during that time 

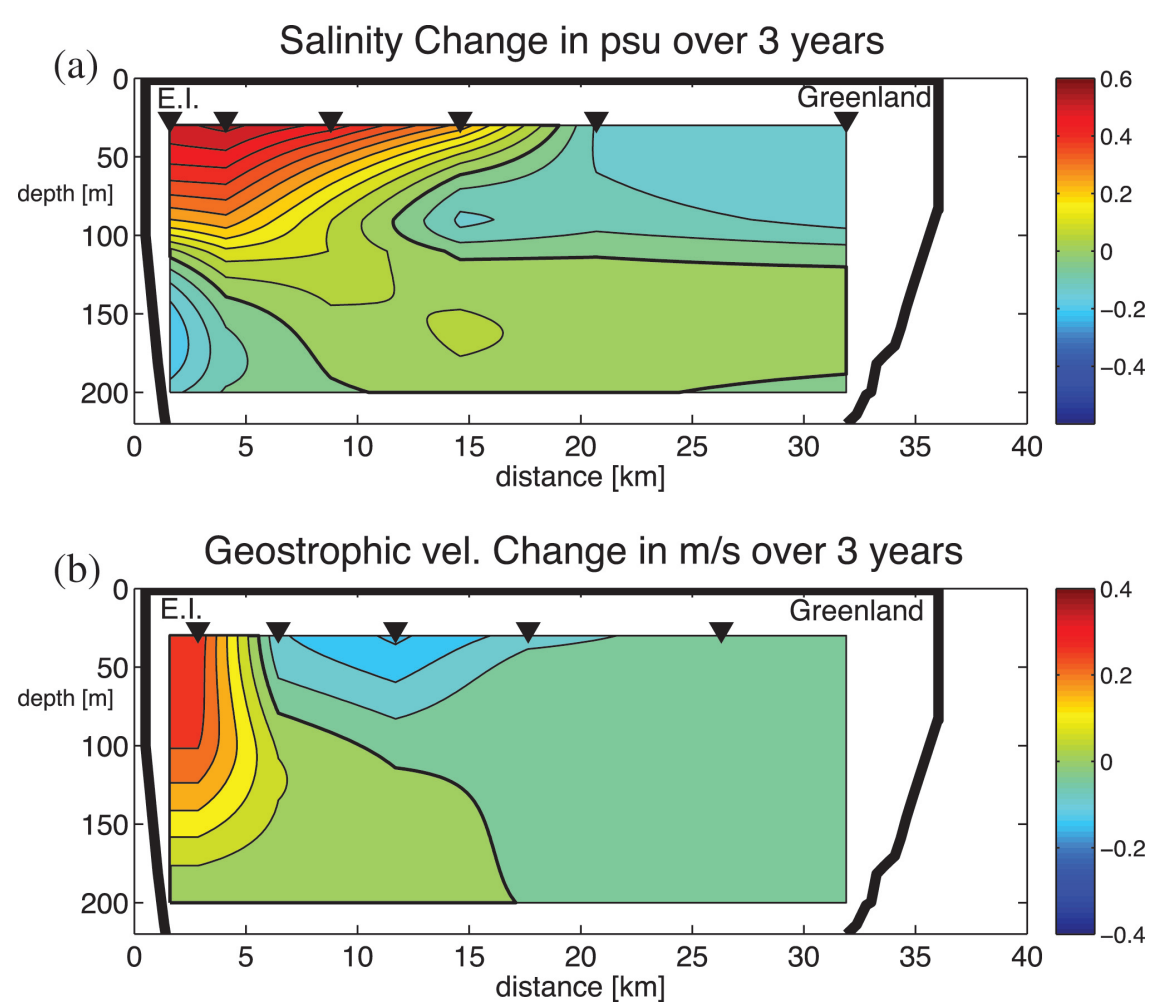

Figure 11. (a) Rate of change of salinity over three years [psu/3 years], with a contour interval of 0.05 $\mathrm{psu} / 3$ years; and (b) rate of change of geostrophic velocity over three years $\left[\mathrm{m} \mathrm{s}^{-1} / 3\right.$ years], with a contour interval of $0.05 \mathrm{~m} \mathrm{~s}^{-1} / 3$ years. Black triangles denote horizontal positions of salinity data points in (a); in (b) each triangle represents the midpoint between two density profiles. The vertical resolution is $1 \mathrm{~m}$. The thicker isoline denotes zero change. The error from sensor drift is explained in detail in Appendix A.

period (Münchow et al., 2011). Changes were largest on the western side, while changes between 120-and 200-m depth within the middle and eastern parts of the strait were close to zero. Salinity decreased in the top layers ( 30 to $100 \mathrm{~m}$ ) on the Greenland side. The sectionally averaged salinity change was $+0.054 \pm 0.009 \mathrm{psu}$; waters became more salty overall. The strong increase in surface salinity off Ellesmere Island indicates fewer freshwater incursions during the last two years. Weaker downwelling-favorable winds were prevalent as compared with the beginning of the record. Surface waters off Ellesmere Island became saltier and thus denser. In contrast, deeper layers became fresher and therefore less dense. Hence the water column in the western part of the strait became less stratified over time with smaller vertical density differences.

ii. Geostrophic velocity. Figure $11 \mathrm{~b}$ shows the change in geostrophic velocity during the three years of observation. Geostrophic velocity increased close to Ellesmere Island (KSO2) 

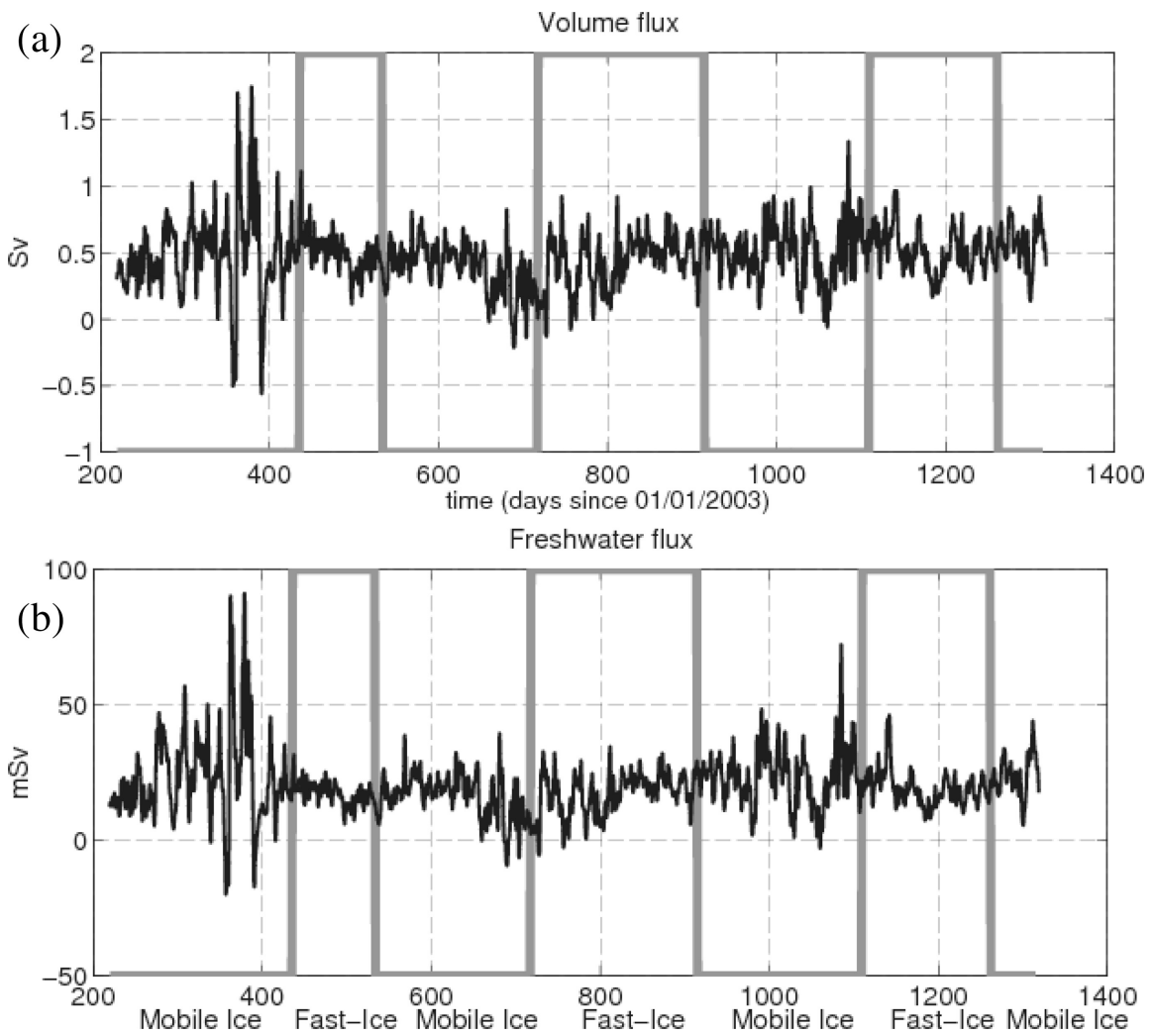

Figure 12. Time series of (a) geostrophic volume flux and (b) geostrophic freshwater flux (relative to $34.8 \mathrm{psu}$ ) through the measured domain. Plotted are the daily values after two-day low-pass filtering. The ice index is also shown (light-gray step function), with positive values representing fast-ice seasons and negative values representing mobile-ice seasons.

by about $0.28 \pm 0.01 \mathrm{~m} \mathrm{~s}^{-1}$ at $50 \mathrm{~m}$ and $0.13 \pm 0.006 \mathrm{~m} \mathrm{~s}^{-1}$ at $150 \mathrm{~m}$. There was a small decrease near the surface in the middle of the strait (KS06) but no change in the lower layers and close to Greenland. The change in salinity at KS01 and KS03 (Fig. 11a: rising isohalines above $120 \mathrm{~m}$, descending at greater depth) is clearly linked to the increase in geostrophic velocity close to Ellesmere Island, although cause and effect here are difficult to establish. The sectionally averaged increase of geostrophic velocities was $0.03 \pm 0.003 \mathrm{~m} \mathrm{~s}^{-1}$; its influence on volume flux will be discussed in Section 4.

\section{Geostrophic volume and freshwater fluxes}

a. Ice-season mean geostrophic fluxes

Figure 12 shows geostrophic-volume and freshwater-flux time series for the measured section, with the ice index overlaid. The magnitude of variability in both fluxes is related 
Table 3. Geostrophic volume and freshwater flux estimates (relative to $34.8 \mathrm{psu}$ ): three-year mean, three-year mean for mobile-ice and fast-ice conditions, and mean flux within each ice season, all with respective degrees of freedom (dof). The domain of integration extends from 30- to 200-m depth and spans about $74 \%$ of the channel's width.

\begin{tabular}{lcccr}
\hline Time & $\begin{array}{c}\text { Geostrophic } \\
\text { Volume } \\
(\mathrm{Sv})\end{array}$ & $\begin{array}{c}\text { Freshwater } \\
\text { dof }\end{array}$ & $\begin{array}{c}\text { Geostrophic } \\
(\mathrm{mSv})\end{array}$ & dof \\
\hline 3-year mean & $0.47 \pm 0.05$ & 191 & $20 \pm 3$ & 135 \\
\hline 3-year mean mobile-ice & $0.47 \pm 0.12$ & 110 & $21 \pm 7$ & 78 \\
3-year mean fast-ice & $0.47 \pm 0.09$ & 81 & $18 \pm 4$ & 57 \\
\hline Mobile-ice 2003 & $0.49 \pm 0.15$ & 36 & $23 \pm 9$ & 26 \\
Mobile-ice 2004 & $0.38 \pm 0.09$ & 33 & $16 \pm 5$ & 23 \\
Mobile-ice 2005 & $0.51 \pm 0.10$ & 34 & $23 \pm 6$ & 24 \\
Mobile-ice 2006 & $0.57 \pm 0.17$ & 7 & $17 \pm 3$ & 5 \\
\hline Fast-ice 2003-2004 & $0.49 \pm 0.10$ & 18 & $17 \pm 4$ & 13 \\
Fast-ice 2004-2005 & $0.43 \pm 0.09$ & 35 & $19 \pm 4$ & 25 \\
Fast-ice 2005-2006 & $0.51 \pm 0.08$ & 28 & & 19 \\
\hline
\end{tabular}

to the ice index. Large fluctuations in flux occurred during mobile-ice seasons in all years, with 2003 being most dramatic. The largest fluxes through the measured section occurred around Jan. 14, 2004 (year day 379); volume flux peaked at $1.76 \mathrm{~Sv}$ and freshwater flux reached $92 \mathrm{mSv}$, both about four times their mean (see Section 4b). Flux variability during fast-ice seasons was smaller than during the mobile-ice seasons.

The seasonal means and uncertainties (95\% confidence limits) of fluxes through the measured section for each ice season are listed in Table 3. Geostrophic freshwater fluxes through the measured section had their largest values during mobile-ice conditions when they were increased by about $20 \%$ relative to fast-ice conditions, with a maximum difference between individual ice seasons of almost $40 \%$. Geostrophic freshwater fluxes through the measured section during mobile-ice seasons were around $23 \mathrm{mSv}$ with uncertainties reaching $9 \mathrm{mSv}$, with the exception of the 2004 mobile-ice season $(16 \pm 5 \mathrm{mSv})$. During fast-ice seasons geostrophic freshwater fluxes through the measured section varied between $17 \pm 4$ and $19 \pm 4 \mathrm{mSv}$. Geostrophic freshwater flux was modulated by the ice conditions, which correlated with the annual freeze-thaw cycle.

Geostrophic volume fluxes through the measured section fluctuated by about $20 \%$ during both ice seasons with no difference in the mean for mobile-ice and fast-ice conditions. The three-year minimum occurred during the mobile-ice season in $2004(0.38 \pm 0.09 \mathrm{~Sv})$, and the maximum during the mobile-ice season in $2006(0.57 \pm 0.17 \mathrm{~Sv})$.

\section{b. Three-year mean geostrophic fluxes}

Integrating the geostrophic velocity over the 30-km-wide section between 30- and 200-m depth (1), we calculate the three-year mean geostrophic volume flux for the measured 
section to be $0.47 \pm 0.05 \mathrm{~Sv}$, which is equivalent to $(15 \pm 2) \times 10^{3} \mathrm{~km}^{3} \mathrm{year}^{-1}$. Note that $0.19 \mathrm{~Sv}(40 \%)$ of this geostrophic volume-flux was introduced by the reference velocity from the ADCP data at $200 \mathrm{~m}$.

Earlier volume-flux estimates were based on shorter-term snapshots only. Sadler (1976) calculated a volume flux of $0.7 \mathrm{~Sv}$ using a 40-day series of current measurements in April to May 1972. Current meters were deployed in Robeson Channel at only three locations leading to low spatial resolution. More than $50 \%$ of the calculated volume-flux by Sadler (1976) was associated with strong currents measured by a single current meter at $100-\mathrm{m}$ depth, $5 \mathrm{~km}$ from Ellesmere Island.

Münchow and Melling (2008) calculated a three-year mean volume flux of $0.57 \pm 0.09$ $\mathrm{Sv}$ from the moored ADCP data collected during this project. Their data reached from about $35 \mathrm{~m}$ below the surface to the seabed, therefore covering $79 \%$ of the total cross-sectional area. Unfortunately, they had to estimate flow speed within a $21-\mathrm{km}$ gap in the section (where ADCPs were not recovered) from the hydrodynamic pull-down of the moorings that provided data for this paper.

Münchow et al. (2006) and Münchow et al. (2007) calculated volume fluxes from two-day-long ADCP snapshots in Kennedy Channel in August 2003. Their estimate of $0.8 \pm 0.3 \mathrm{~Sv}$ was based on the geostrophic velocity field calculated from a CTD section and referenced to the ADCP data, spanning 350- to 35-m depth over a 32-km wide section, and using 2-km across-channel binning. The section area was $8.7 \mathrm{~km}^{2}, 81 \%$ of the total cross section. About $1 / 3$ of that volume flux $(0.27 \mathrm{~Sv})$ was associated with the reference level velocity. The estimate of $0.91 \mathrm{~Sv}$ included an extrapolation to the surface which added about $10 \%$ to the net flux observed below $30 \mathrm{~m}$.

Using our data for this same snapshot in time during the two-day period (Aug. 6-8, 2003), we estimate the geostrophic volume flux through our measured section to be $0.33 \pm 0.08 \mathrm{~Sv}$. These different flux numbers at the same point in time act as a calibration point between the different measurement techniques. Our geostrophic volume-flux is around $40 \%$ of the volume fluxes calculated from ADCP measurements, making these estimates very roughly comparable in magnitude when considering the different cross-sectional areas covered ( $81 \%$ and $48 \%$ of the total cross-section). We emphasize, however, that the inherent temporal variability in fluxes evident from Figure 12 suggests that estimates based on snapshots of the flow field, hydrography, or both cannot in general be relied on to represent the mean.

We calculate a mean geostrophic freshwater flux for the measured section by taking the time mean of the freshwater flux time series (2). The three-hourly geostrophic velocity $u_{g}(y, z, t)$ is multiplied by the three-hourly salinity anomaly $F_{a}(y, z, t)$ before integrating over the section and then taking the temporal mean $(<>$ denoting time mean): $<\int_{A} u_{g}(y, z, t) \times F_{a}(y, z, t) d A>$. The result of this freshwater flux calculation is $20 \pm$ $3 \mathrm{mSv}$ or $630 \pm 95 \mathrm{~km}^{3} \mathrm{year}^{-1}$, using a reference salinity $S_{0}$ of 34.8 psu. The reference velocity at $200 \mathrm{~m}$ accounted for $7 \mathrm{mSv}(35 \%)$ of the geostrophic freshwater flux. Therefore, $13 \mathrm{mSv}$ were associated with the baroclinic component of the freshwater flux through the measured section. For the freshwater flux the missing top $30 \mathrm{~m}$ are more crucial than for the 
volume flux as salinity is significantly reduced in that layer (Figs. 5 and 6; also see Melling (2000)). Our estimate thus provides a lower bound only.

When calculating the geostrophic freshwater flux from the product of the three-year mean of geostrophic velocity $<u_{g}(y, z, t)>$ and salinity anomaly $<F_{a}(y, z, t)>$ using: $\int_{A}<$ $u_{g}(y, z, t)>\times<F_{a}(y, z, t)>d A$, the three-year mean is also $20 \mathrm{mSv}$. This suggests that the freshwater flux occurs principally at low frequencies and that covariance between $u_{g}$ and $F_{a}$ at shorter timescales (daily to seasonal) must be small. This is encouraging for efforts to determine freshwater flux from larger-scale variables such as the mean sea-level slope and difference in freshwater content between Baffin Bay and the Lincoln Sea.

We find that about $90 \%$ of the freshwater flux variance is explained by the variability in volume flux at low frequencies. The variance of the freshwater flux explained by the salinity variability is not statistically significant. Salinity at 30-m depth was used to perform this calculation, since this exhibits the most variability and is most likely to influence variability in the freshwater flux. Note that, since freshwater is added to the ocean at the surface, the covariance between freshwater and salinity is likely to increase toward the surface. This important fast-moving, low-salinity part of the water column was not accessible to our instruments. With the data at hand, we can conclude only that the variance in the freshwater flux beneath the 30 -m surface layer is almost entirely linked to variance in the volume flux within the same range of depths (as one might expect from Fig. 12).

Münchow et al. (2007) calculated $30 \mathrm{mSv}$ for the freshwater flux across a section in Kennedy Channel in 2003. This estimate covered almost the entire cross-section, and included a surface extrapolation, which added about $10 \%$ to the net freshwater flux observed below $30 \mathrm{~m}$.

During the same time period from Aug. 6-15, 2003, our geostrophic freshwater flux estimate for the measured section is $14 \pm 4 \mathrm{mSv}$. A preliminary extrapolation to the full cross section (including estimates for the surface layer as described in the next section) would lead to about $34 \mathrm{mSv}$. No attempt has been made to weight the important surface layer appropriately, and this first approximation demonstrates that the two different calculations are roughly comparable.

As with the volume flux through the strait, there is large variability in freshwater flux on a wide range of timescales (Fig. 12). These first long-term measurements of three years' duration place previous short-term measurements into a larger temporal context. Our measurements make it clear that short-term measurements are always biased by strong events at weekly and seasonal timescales and need to be evaluated with caution.

\section{c. Geostrophic freshwater flux extrapolation to the surface}

We estimate the geostrophic freshwater flux in the top $30 \mathrm{~m}$ on the basis of the following assumptions. First, we assume that during mobile-ice seasons there was no shear in geostrophic velocity between $30 \mathrm{~m}$ and the surface; that is, $u_{g}(z=0)=u_{g}(z=30 \mathrm{~m})$. This is a very conservative assumption, since floating ice at the surface is known to drift 


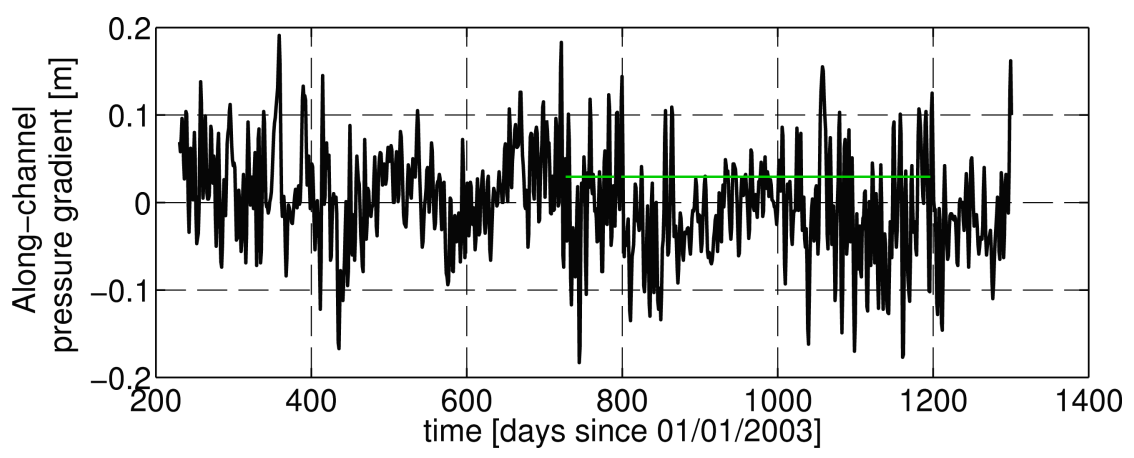

Figure 13. Time series of two-day, low-pass-filtered, along-channel pressure difference after Münchow and Melling (2008), as explained in Section 2. Daily values are plotted in meters of equivalent sea-level difference. Positive values indicate that the pressure is higher in the north.

faster than the current at 30-m depth. During fast-ice seasons we assume a linear decrease in velocity toward $u_{g}(z=0)=0$ at the static ice cover. We further assume that salinity within the top $30-\mathrm{m}$ is $S(z=0)=S(z=30 \mathrm{~m})$. This assumption is probably good in winter when surface mixed layers are deep and uniform, but it overestimates salinity and underestimates freshwater flux when melt water is present during June through October.

With these conservative assumptions, we estimate-an additional $12 \mathrm{mSv}$ of geostrophic freshwater flux through the measured section during the mobile-ice season, and an additional $1 \mathrm{mSv}$ during the fast-ice season. These estimates indicate that the geostrophic freshwater flux in the surface layer under mobile ice is a substantial fraction of the total freshwater flux through Nares Strait. Since mobile ice occurs $60 \%$ of the time, the three-year mean geostrophic freshwater flux through the measured section can be estimated as at least $28 \mathrm{mSv}$. The top $30 \mathrm{~m}$ thus contributed more than $40 \%$ of the long-term mean geostrophic freshwater flux. Note that freshwater carried as ice through Nares Strait has not yet been incorporated in our estimates and that our measured section does not span the entire width of the strait.

\section{Forcing}

\section{a. Pressure-difference forcing}

An important factor governing the flow through straits is the pressure difference along the strait (Garrett and Toulany, 1982). Kliem and Greenberg (2003) show that in numerical simulations an increase in sea-level elevation by $0.1 \mathrm{~m}$ in Baffin Bay relative to the Arctic Ocean results in a decrease in volume transport by $0.5 \mathrm{~Sv}$ through Nares Strait. Münchow and Melling (2008) found that the along-chammel pressure difference accounts for $60 \%$ of the variance at the 20-day period with no phase lag for sectionally averaged flows. Figure 13 shows the 2003-2006 time series of anomalies in along-channel pressure difference between Alert and Smith Sound, from Münchow and Melling (2008) as explained in Section 2. 
This section evaluates the link between the pressure difference and the freshwater flux for both ice states in the frequency domain. Coherence squared $\Gamma^{2}$ estimates the degree of linear correlation between two signals as a function of frequency. We subdivide each time series into 10 non-overlapping time series and ensemble average the 10 separate estimates to decrease uncertainty in estimated parameters at reduced frequency resolution. We focus solely on geostrophic freshwater fluxes, since geostrophic volume and freshwater fluxes are highly correlated with a correlation coefficient $r^{2}$ of around 0.90 .

$\Gamma^{2}$, phase, and gain between the along-channel pressure difference and the geostrophic freshwater flux are plotted in Figure 14 for mobile-ice seasons. $\Gamma^{2}$ was significantly different from zero at all frequencies. The highest correlation occurred at 0.12 cycles per day (cpd) (or a period of eight days). Almost one-third of the variance in geostrophic freshwater flux was accounted for by the pressure difference at this weekly timescale. At other frequencies about $20 \%$ of the variance was accounted for. The phase for the peak at eight days was around $-10^{\circ}$, which means that the along-channel pressure difference was leading the geostrophic freshwater flux by roughly a quarter of a day. The gain was almost $160 \mathrm{mSv} \mathrm{m}^{-1}$ at weekly timescales; that is, a change in sea level of $1 \mathrm{~m}$ results in a geostrophic freshwater flux change of $160 \mathrm{mSv}$. At higher frequencies the phase fluctuated among $+30^{\circ}$ at $0.22 \mathrm{cpd}$ ( 4.5 days), $-30^{\circ}$ at $0.4 \mathrm{cpd}$ ( 2.5 days), and $+15^{\circ}$ at the highest frequencies; these large fluctuations relate to channel dynamics at different timescales. Both barotropic and baroclinic pressure differences play a role in this dynamically wide strait (Münchow et al., 2006), as well as possibly baroclinic waves that propagate through the strait (e.g., Johnson and Garrett, 2006).

Since the along-channel pressure difference also has an effect on the flow during fast-ice seasons, we calculate $\Gamma^{2}$, phase, and gain for the fast-ice seasons as well (Fig. 15). We exclude the first 2003-2004 fast-ice season from our analysis as it was much shorter, and focus on the averaged spectral results (in the frequency domain) over those two remaining fast-ice seasons. During the fast-ice seasons $\Gamma^{2}$ exceeded the $95 \%$ confidence level at frequencies below $0.15 \mathrm{cpd}$ ( 6.7 days), meaning that coherence at higher frequencies cannot be distinguished from zero. Therefore, the along-channel pressure difference forcing influences the freshwater flux in a statistically significant manner only on timescales longer than weekly. The phase was zero at the lowest frequencies and the along-channel pressure difference was therefore in-phase with the geostrophic freshwater flux. The gain varied between 50 and $100 \mathrm{mSv} \mathrm{m}^{-1}$ (50-100 mSv change per $1 \mathrm{~m}$ ), with a higher gain the lower the frequency. The results presented here are consistent with those presented by Münchow and Melling (2008) for sectionally averaged velocities.

\section{b. Local wind forcing}

The three-year mean along-channel wind speed in Nares Strait from the atmospheric model (Samelson and Barbour, 2008) is plotted in Figure 7. Wind speed was calculated for a height of $10 \mathrm{~m}$; the wind was predominantly toward the south with maximum values exceeding $15 \mathrm{~m} \mathrm{~s}^{-1}$ and at times towards the north with a maximum speed of $10 \mathrm{~m} \mathrm{~s}^{-1}$. 

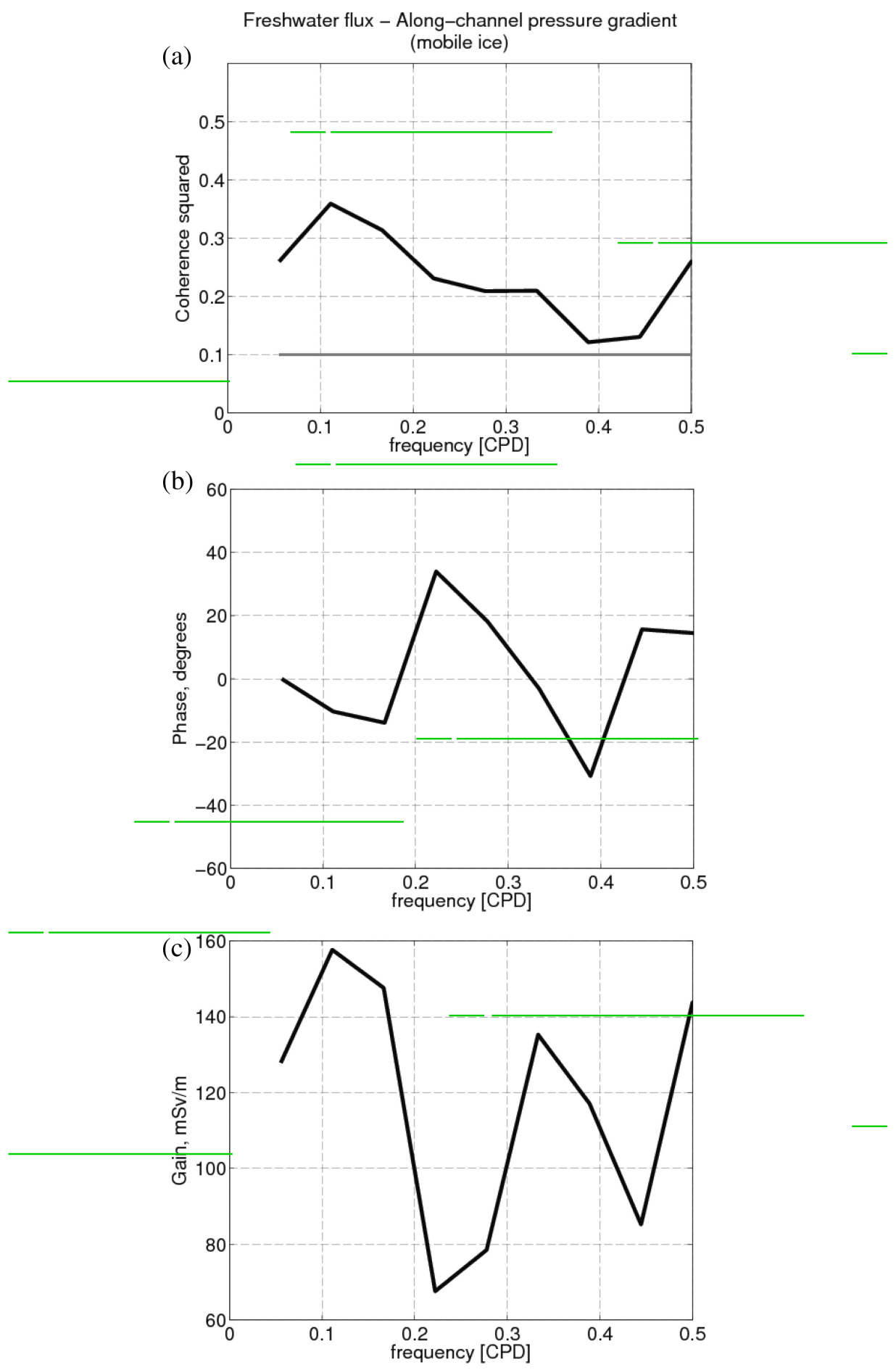

Figure 14. (a) Coherence squared, (b) phase (degrees), and (c) gain $\left(\mathrm{mSv} \mathrm{m}^{-1}\right)$ between geostrophic freshwater flux and along-channel pressure difference during mobile-ice seasons $(185$ davs per 
(a) Freshwater flux - Along-channel pressure gradient (fast-ice)
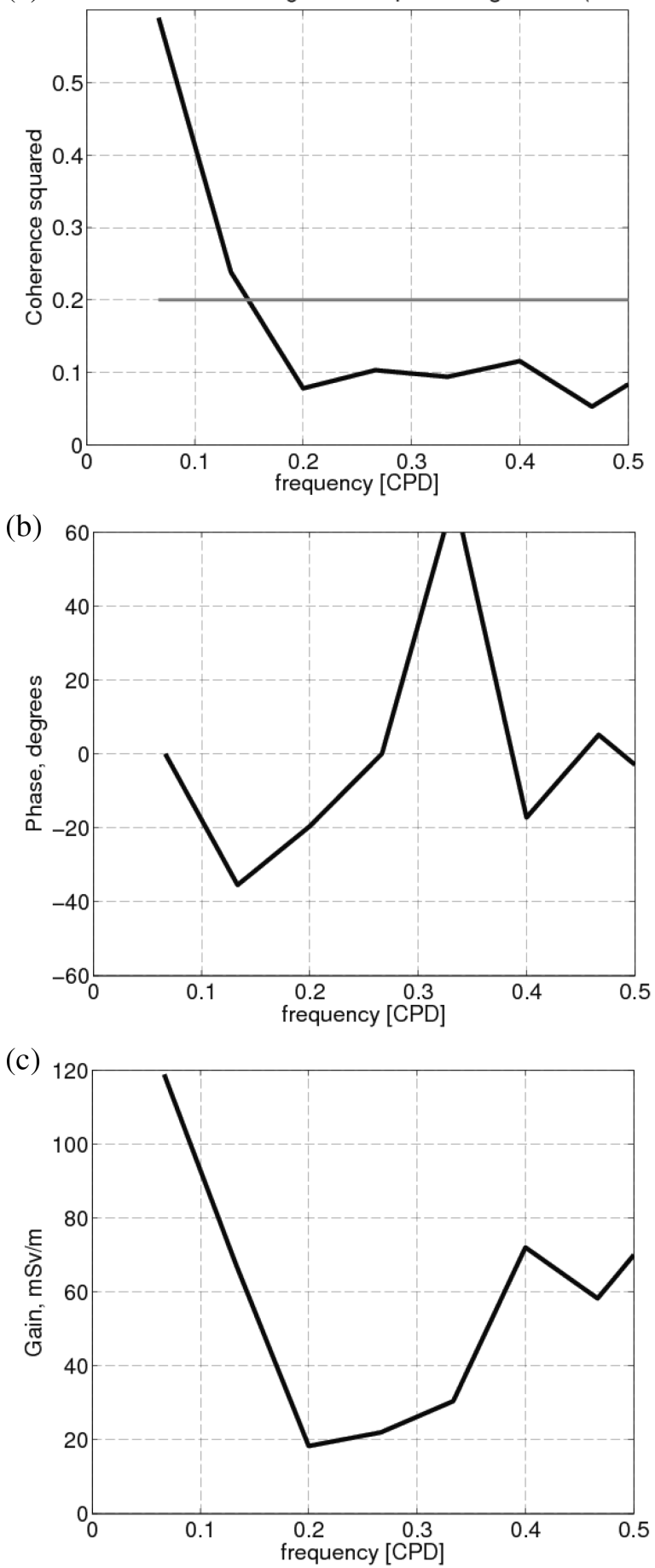

Figure 15. (a) Coherence squared, (b) phase (degrees), and (c) gain $\left(\mathrm{mSv} \mathrm{m}^{-1}\right)$ between geostrophic freshwater flux and along-channel pressure difference during fast-ice seasons in 2004-2005 and 
During fast-ice seasons, the local wind stress did not affect the channel flows. During mobileice seasons, however, the wind acted as a local forcing agent. Münchow and Melling (2008) found no correlation between wind stress and the sectionally averaged ADCP currents using the entire three-year record, which contained seasons of both moving-ice and fast-ice. The period and timing for both ice stages change from year-to-year. We evaluate the coherence between the geostrophic freshwater flux and the local wind separately for mobile-ice and fast-ice conditions.

In the frequency domain we calculate partial $\Gamma^{2}$, phase, and gain for mobile-ice seasons from 2003 to 2005. Partial coherence is calculated using linear system analysis to evaluate the component of the local wind that is not correlated with the along-channel pressure difference. This is necessary, because the along-channel wind and along-channel pressure difference are closely related. This analysis allows us to distinguish between purely local wind forcing and larger-scale pressure-difference forcing.

Partial $\Gamma^{2}$ during the mobile-ice season was significantly different from zero at all frequencies lower than $0.37 \mathrm{cpd}$ (2.7 days) (Fig. 16a). A maximum correlation of 0.4 occurred at a frequency of about $0.12 \mathrm{cpd}$ (eight days). The phase was negative, i.e., local wind led the geostrophic freshwater flux. A phase of $-50^{\circ}$ at a frequency of $1 / 6 \mathrm{cpd}$ indicates that the local wind leads geostrophic freshwater flux by one day. The gain fluctuated around $1 \mathrm{mSv}\left(\mathrm{m} \mathrm{s}^{-1}\right)^{-1}$ at frequencies below $0.37 \mathrm{cpd}$ (2.7 days). Therefore a $10 \mathrm{~m} \mathrm{~s}^{-1}$ southward wind generates a freshwater flux of $10 \mathrm{mSv}$ during the mobile-ice season. For comparison, to generate a similar freshwater flux of $10 \mathrm{mSv}$ with an along-channel pressure difference, a pressure difference of $0.06-0.1 \mathrm{~m}$ is needed, depending on the ice cover.

The partial $\Gamma^{2}$ between the local wind and the geostrophic freshwater flux during fast-ice seasons (Fig. 16a) was, as expected, below the $95 \%$ confidence level at all frequencies (light gray line). Wind and geostrophic freshwater flux thus are uncorrelated when the ice is fast. Phase and gain are therefore without meaning and not shown.

Summarizing, we find local wind and geostrophic freshwater flux to be coherent at frequencies below $0.37 \mathrm{cpd}$ ( 2.7 days) during mobile-ice seasons with the local wind leading the geostrophic freshwater flux by approximately a day.

\section{Discussion}

The surface layer is crucial for the freshwater flux in Nares Strait as it carries the freshest water and ice. In our first geostrophic freshwater flux estimates the top $30 \mathrm{~m}$, where no data exist, were not included, but then a crude extrapolation to the surface (no ice) led to an increase by $40 \%$. This is a lower bound because we used a constant salinity in the top $30 \mathrm{~m}$ although salinity decreases toward the surface. This underestimates the summer freshwater flux when fresher water exists at the surface (e.g., Münchow et al. (2006)). Furthermore, the assumption of a uniform velocity throughout the top $30 \mathrm{~m}$ is again an underestimate as floating ice at the surface drifts much faster than the velocity measured at $30 \mathrm{~m}$ suggests. Melling (2000) reviewed freshwater estimates from Prinsenberg and Bennett (1987) and speculated that up to $50 \%$ of the flux in summer occurs in the upper $10 \mathrm{~m}$. In winter, $50 \%$ of the flux 

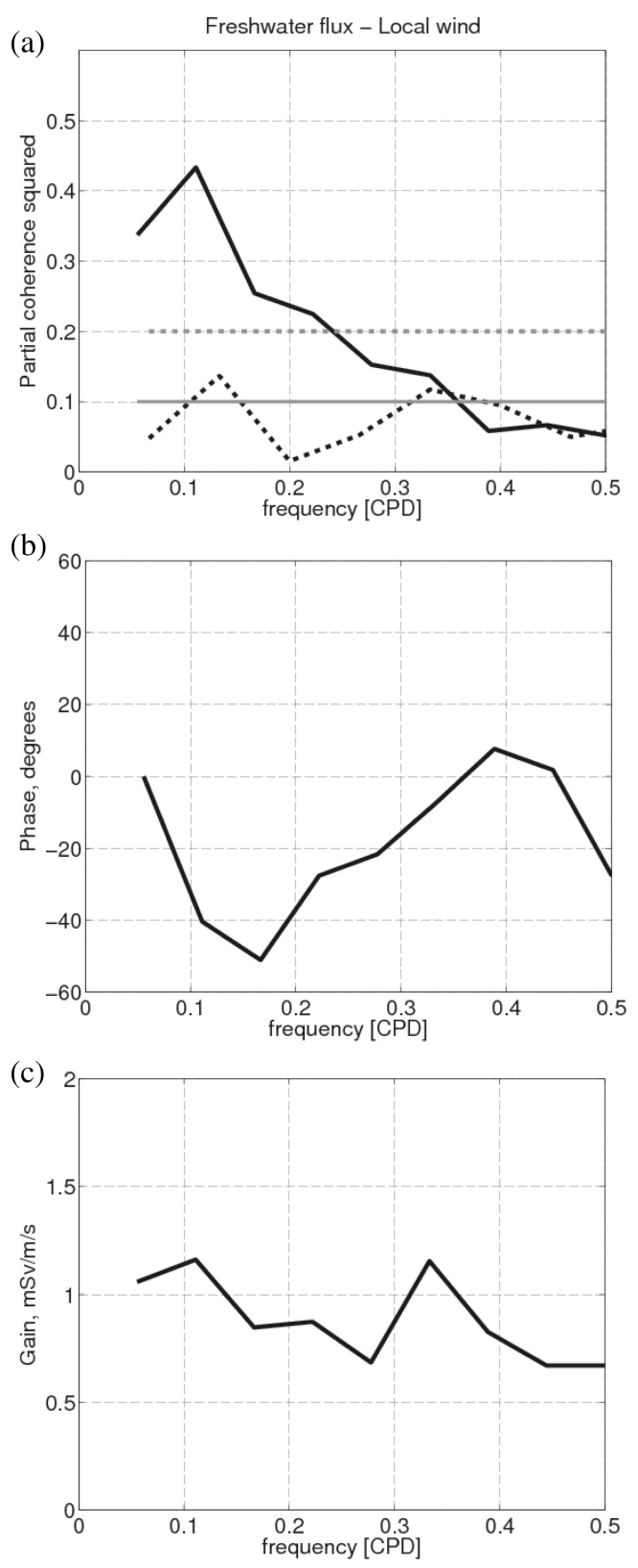

Figure 16. (a) Partial coherence squared, (b) phase (degrees), and (c) gain $\left(\mathrm{mSv}[\mathrm{m} / \mathrm{s}]^{-1}\right.$ ) between geostrophic freshwater flux and that part of the local wind stress that is not correlated with alongchannel pressure difference. In (a) the solid black line denotes the partial coherence squared during mobile-ice seasons, with the solid gray line indicating the corresponding 95\% confidence level. The dotted black line is the partial coherence squared during fast-ice seasons in 2004-2005 and 20052006, with the gray dotted line indicating the corresponding 95\% confidence level. Partial coherence squared is always below the $95 \%$ confidence level for fast-ice conditions, so the respective phase and gain are not plotted. 
is concentrated in the top $44 \mathrm{~m}$. Our extrapolation suggests at least a $40 \%$ contribution to the geostrophic freshwater flux from the top $30 \mathrm{~m}$ during mobile-ice summer seasons.

The geostrophic freshwater flux and along-channel local wind or pressure difference show a maximum correlated variance at weekly timescales. The combined influence of wind and along-channel pressure difference on variability in the geostrophic freshwater flux at weekly timescales supports earlier observations of flow variability made in northern Baffin Bay by Melling et al. (2001). They state that fluctuations in the flow through Smith Sound are forced in part by the higher sea level of the Arctic Ocean and in part by winds channeled between the mountains of Greenland and Ellesmere Island. These fluctuations have a period of five to 10 days, consistent with our findings. Throughout this paper we refer to geostrophic velocities and fluxes. Note that Münchow and Melling (2008) concluded that a substantial fraction of the along-channel flow is in geostrophic balance while Münchow et al. (2006) found (from a two-day survey) that two-thirds of the flux through the section was dynamically consistent with geostrophy, with the remaining one-third associated with barotropic influences.

Geostrophic velocity and freshwater flux calculated in this study exhibit variability on all time scales from weekly to interannual. Traditional ways to present variability as monthly means and annual cycles are not appropriate in Nares Strait, since they do not account for variability in the ice cover which is the dominant influence on the flow. Also, there is substantial variance at 10 to 20 days that is ignored in monthly averages. The large variability of freshwater flux shows that short-term observational campaigns may over- or underestimate the mean freshwater flux.

On the basis of our results, we speculate that a transition toward a longer mobile-ice season would lead to increased freshwater flux, with the system responding more strongly to time-dependent local and remote forcing. Enhanced freshwater flux could in turn lead to changes downstream. Changes in the Lincoln Sea upstream may also play a role; an increase in freshwater content has recently been observed there (Timmermans et al., 2011).

Many of the features of flow through Nares Strait depend on the drift state of the ice cover, which depends in turn on whether or not an ice bridge forms in Smith Sound in winter. Over the last 20 years, 1991-1992 to 2010-2011, an ice bridge did not form to stabilize fast-ice in Nares Strait in five winters-1992-1993, 1994-1995, 2006-2007, 2008-2009, 2009-2010 (Agnew, 1998; Vincent and Marsden, 2001; Münchow et al., 2007; Kwok et al., 2010; and Canadian Ice Service Weekly Ice Chart). Events of this type have been documented back to as 1962-1963 (Dunbar, 1969). It is clearly premature to suggest that Nares Strait is in transition from a seasonally land-fast to a constantly mobile condition. However, it is clear from our results that if such a transition were to be a consequence of climate change, the impact on oceanic fluxes would be appreciable.

Some of these changes are predicted by numerical simulations of the Nares Strait iceocean-atmosphere system. For example, Rasmussen et al. (2010) show an increasing trend in the volume flux through Nares Strait for 2007 and 2008. They speculate that this increase in volume flux might be one of the reasons for the lack of formation of an ice arch in those winters. Earlier work by Yao and Tang (2003) showed a correlation between the volume 
flux and the stability of ice arches. Longer mobile-ice seasons imply larger freshwater fluxes. Furthermore, such change also implies an extended period of thick multiyear ice streaming south from the Lincoln Sea. In combination, such conditions may increase the total freshwater flux south through Nares Strait. Changes in the duration of land-fast ice seasons would also impact vertical and horizontal stratification as well as the larger-scale distribution, transit time, and pathways of Arctic freshwater.

\section{Summary}

This paper presents an analysis of a three-year mooring data set from 2003 to 2006 from Nares Strait, separating northern Canada (Ellesmere Island) from Greenland, with a focus on the temporal variability of salinity, geostrophic velocity, and volume and freshwater fluxes on different timescales, as well as their relation to the along-channel wind and pressure differences.

We developed a novel CT mooring design for this project (with low buoyancy above $200 \mathrm{~m}$, leading to significant pull-down of instruments) which successfully solved a major challenge facing mooring installations in the CAA: iceberg and sea-ice keel encounter and the associated threat to instruments. The pull-down of instruments additionally allowed a high-vertical-resolution salinity data set to be constructed using a multiple linear regression model as a novel pre-processing tool.

The geostrophic freshwater flux was larger (by about 20\%) and more variable during mobile-ice than fast-ice seasons, with maximum differences between individual ice seasons of $40 \%$. The three-year mean geostrophic freshwater flux was $20 \pm 3 \mathrm{mSv}$ (excluding ice) for the measured domain (74\% of the cross-sectional area above $200 \mathrm{~m}$, excluding the top $30 \mathrm{~m}$ ). A simple extrapolation suggests that the geostrophic freshwater flux in the top $30 \mathrm{~m}$ is negligible during fast-ice seasons $(<5 \%)$ but contributes more than $40 \%$ of the longterm mean geostrophic freshwater flux during mobile-ice seasons. This emphasizes the importance of reliable measurements in the surface layer especially during the mobile-ice season. As demonstrated by Melling (2000), approximately half of the Arctic freshwater flux moves in the upper $35 \mathrm{~m}$ of the ocean. Because we have only approximate data on the current in the top layer and no data on the salinity, we cannot yet provide useful estimates of the total freshwater flux through Nares Strait. The value quoted here is certainly low by a large factor, and others' estimates for other straits may be similarly imprecise. For these reasons, we do not presume to re-assess the Arctic's freshwater budget in the light of our new data.

No significant temporal change in geostrophic freshwater flux was observed over the three years (Table 4). In contrast to the geostrophic freshwater flux, the geostrophic volume flux (at depths greater than $30 \mathrm{~m}$ ) was not modulated by the ice cover, but showed a statistically significant increase of $15 \pm 4 \%$ over the three years (Table 4). Münchow and Melling (2008) also found a $20 \pm 10 \%$ volume flux increase from ADCP data over the same time period. The 3-year mean of volume flux for the measured domain was $0.47 \pm 0.05 \mathrm{~Sv}$. Variability in 
Table 4. Geostrophic volume and freshwater flux offset $(\mathrm{Sv} / \mathrm{mSv})$ and trends $\left(\mathrm{Sv} / \mathrm{mSv}_{\mathrm{sear}}{ }^{-1}\right)$ with uncertainties, finding a linear trend after the mean has been removed. The domain of integration extends from 30- to 200-m depth and spans about $74 \%$ of the channel's width. A significance test to get the $95 \%$ confidence intervals using the null hypothesis according of Fofonoff and Bryden (1975) was used to calculate uncertainties.

\begin{tabular}{lcc}
\hline Geostrophic Flux & Offset & $d q / d t$ and $d F / d t$ \\
\hline Volume & $-0.051 \pm 0.013 \mathrm{~Sv}$ & $0.024 \pm 0.006 \mathrm{~Sv}_{\text {year }}{ }^{-1}$ \\
Freshwater* & $-0.494 \pm 0.585 \mathrm{mSv}$ & $0.235 \pm 0.257 \mathrm{mSv}^{-1}$ \\
\hline
\end{tabular}

*Not significant.

the geostrophic volume (and freshwater) flux was large, however, suggesting that estimates from short-term surveys give biased values that may not represent the long-term mean.

The geostrophic freshwater and volume flux in Nares Strait were partially forced by both along-channel local winds and along-channel pressure differences. The maximum correlated variance occurred at weekly time scales. During the mobile-ice seasons local wind and along-channel pressure differences accounted for $80 \%$ of the total variance. The alongchannel pressure difference contributed $35 \%$ of the variance while local winds accounted for $45 \%$. During the fast-ice seasons the variance reached $40 \%$ at a period of eight days, with the along-channel pressure difference accounting for all of that variance; local wind had no effect as the flow is decoupled from the atmosphere through the ice cover. Changing atmospheric and ice conditions have a strong impact on fluxes through Nares Strait only via remote pressure differences.

Geostrophic velocities demonstrated large variability over different timescales and a strong dependence on the ice cover. In the western part of the strait, maximum geostrophic velocities occurred during fast-ice seasons and were concentrated in a subsurface core close to Ellesmere Island. During mobile-ice seasons a maximum existed in the middle of the strait in the surface layer. Much smaller geostrophic velocities existed close to Greenland. During mobile-ice seasons the geostrophic flows reversed their direction on short time scales. Between 2003 and 2006 there was a transition during mobile-ice conditions from a single-velocity maximum in the center of the channel to a double-cored structure, with an additional velocity maximum developing adjacent to Ellesmere Island, reminiscent of that which is present during fast-ice conditions. The latter first appeared in the 2005 mobile-ice season and, we speculate, is linked to changing ice conditions in the strait.

Salinity observations indicated frequent freshwater incursions during mobile-ice seasons and more steady conditions during fast-ice seasons. We identified upwelling and downwelling events on both sides of the strait. During mobile-ice seasons, strongly negative salinity anomalies on the western side of the strait are linked to both strong southward wind events (advecting freshwater into Nares Strait by wind-induced currents) and increased local melting.

Ocean conditions in Nares Strait fluctuate dramatically in response to changing ice conditions, wind, and remote forcing via pressure differences. An understanding of this baseline 
variability provides the essential context for determining the Arctic freshwater budget and for understanding long-term change in the Arctic. These first long-term measurements at high spatial and temporal resolution have made a significant contribution to developing such context and understanding. An extension of this data set from 2007-2009 will more firmly establish whether the time-dependent changes in the strait continue.

Acknowledgments. We thank the officers and crew of USCGC Healy and CCGS Henry Larsen for all their hard work during deployment and recovery. We also thank the capable technicians Peter Gamble, Jo Poole, Ron Lindsay and Dave Huntley, who were essential to the success of the mooring component of this project. Thanks to Pat Ryan for helping with tables, Pablo Huq for fruitful discussions, and the two anonymous reviewers for helpful suggestions. Support for this work comes from the National Science Foundation, grant no. 0230236, and from the Canadian Department of Fisheries and Oceans for salaries and institutional and logistical infrastructure. HLJ is funded by a Royal Society University Research Fellowship, for which she is very grateful.

\section{APPENDIX A}

\section{Calibration}

All instruments were calibrated by SeaBird Electronics prior to deployment. Discrepancies between true and measured salinity result predominantly from drift in conductivity, not temperature sensors. Typically, cell fouling biases conductivity sensor readings toward lower values. Cell fouling decreases salinity by about 0.05 psu per year in Arctic environments, with maximum drifts of several tenths of a psu (on the basis of prior experience with Arctic deployments). In the equatorial Pacific, Ando et al. (2005) found maximum SBE37 conductivity drifts of 0.010 and $0.0053 \mathrm{~S} \mathrm{~m}^{-1}$ to lower values after a one-year deployment in the top and thermocline layers, which is equivalent to decreases of 0.065 and $0.034 \mathrm{psu}$ at $30^{\circ} \mathrm{C}$. Freitag et al. (1999) also found conductivity drifts of the same magnitude in other similar SeaBird instruments.

Ando et al. (2005) found that the drift of the conductivity sensors in the shallower layers was caused by the environment, such as biofouling and scouring effects related to current speed. Biofouling in Nares Strait is limited and even shallow moorings revealed little noticeable fouling after a three-year deployment.

To estimate an upper bound on conductivity drift, we use data from CT instruments deployed $2 \mathrm{~m}$ above the seafloor. At these approximately 300-m-deep locations, water masses are stable with only small salinity variations (see Figs. 5 and 6). These instruments represent a worst case concerning sediments because of their proximity to the seafloor.

Figures 17a and b show histograms of bottom salinity at sites KS02a and KS10a. The histograms show the salinity values for the first and last three months of the record. Salinity shifted toward fresher conditions over the three years. A Gaussian normal distribution is shown for comparison in gray. The offset between the two Gaussian curves is a conservative estimate of error for the salinity data, as it includes drift and signal.

Figures $17 \mathrm{c}$ and $\mathrm{d}$ illustrate histograms of temperature at the same sites. The distribution is normal again with a shift towards lower temperatures by about 0.05 to $0.08{ }^{\circ} \mathrm{C}$ over 

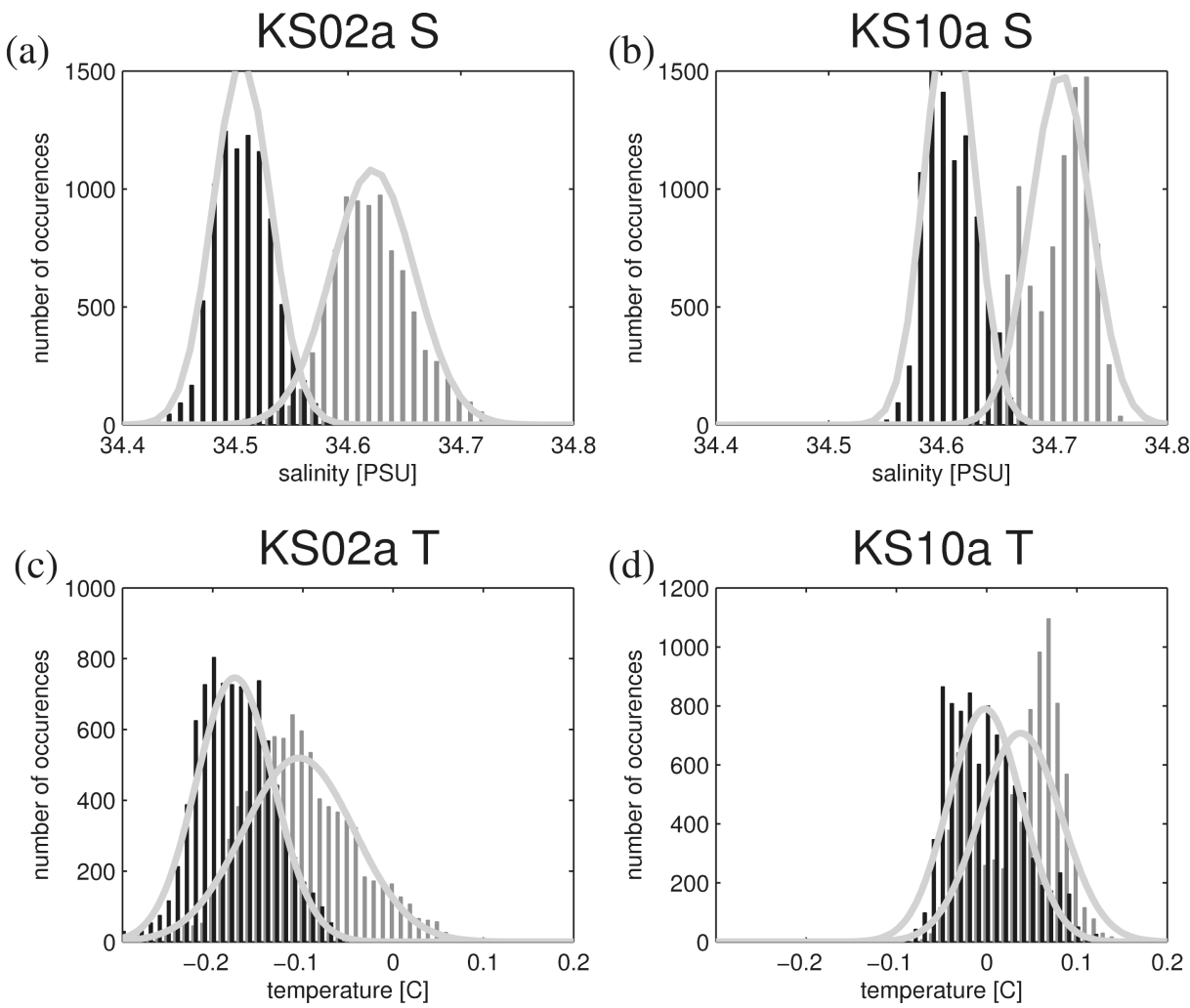

Figure 17. Salinity and temperature data from bottom-mounted CT instruments at KSO2a (a and c) and $\mathrm{KS} 10 \mathrm{a}$ (b and d). (a) and (b) are histograms of salinity for the beginning (first three months, gray) and end (last three months, black) of the three-year record, with a Gaussian distribution overlaid. Salinity values are approximately normally distributed, and shift toward lower salinity during the deployment period. (c) and (d) are histograms of temperature for the beginning (first three months, gray) and end (last three months, black) of the record, again with a Gaussian distribution overlaid. Temperatures also shift toward lower values during the deployment period.

the three years. Temperature sensors are generally stable over time so we speculate that this drift is associated with a cooling of the water mass at the bottom of Nares Strait. The concurrent cooling and freshening of bottom waters in Nares Strait may relate to a change of the Atlantic influence. We conclude that drifts in salinity and geostrophic velocity are not entirely due to conductivity sensor drift, but are also likely to include real signals associated with changing water-mass characteristics in Nares Strait.

We can consider the magnitude of salinity change expected given the temperature change between the beginning and end of the deployment. The slope of the T-S relation from bottom-mounted moorings at KS02a and KS10a predicts how much salinity change corresponds to a given temperature change (Fig. 18). The difference between salinity at the 

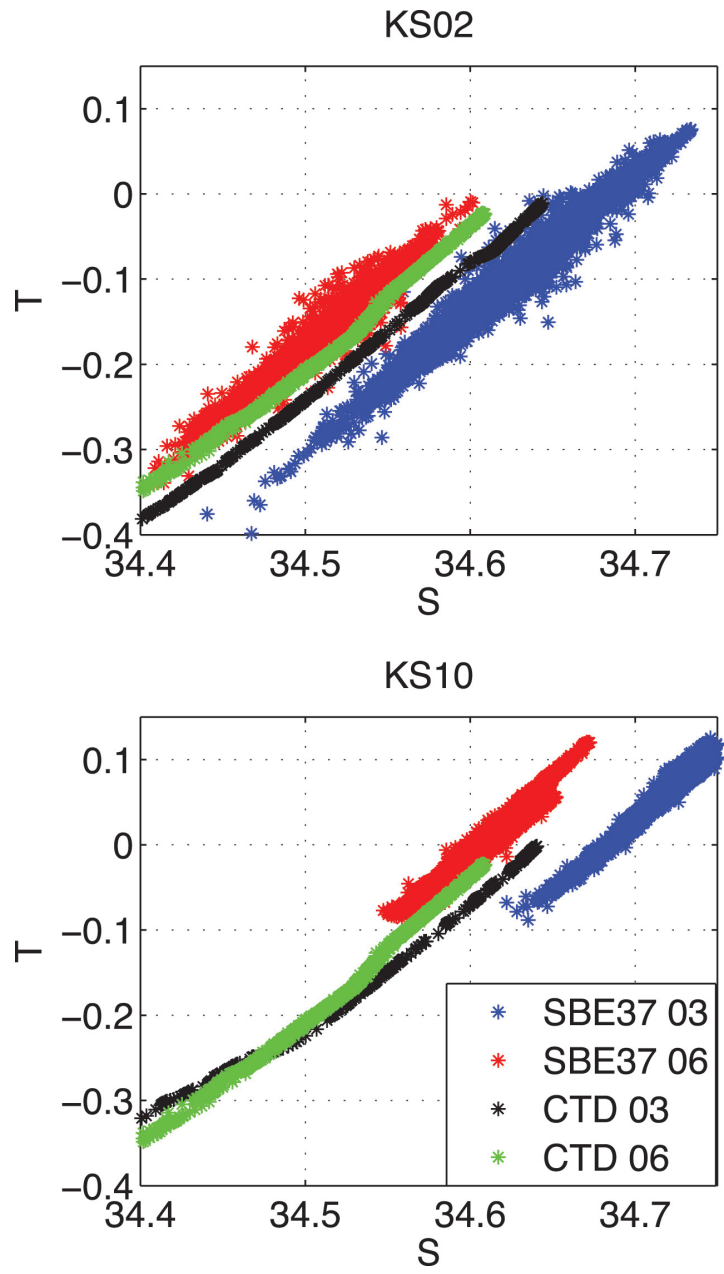

Figure 18. TS diagrams at KS02 and KS10 for the first (blue) and last (red) three months of the CT mooring data. Independently calibrated CTD data collected in 2003 at KS03 (close to KS02) and KS11 (close to KS10) are plotted in black. CTD data collected in 2006 at KS10 are also plotted in green.

beginning and the end of the record at both locations indicates a change of about $0.08 \mathrm{psu}$ over the three years. Instantaneous and independently calibrated CTD measurements in 2003 and 2006 are plotted at locations KS03 and KS11 in 2003, and KS10 in 2006 (assuming that conditions at depth are representative across the whole strait). The CTD data indicate a change of $0.03{ }^{\circ} \mathrm{C}$ at both locations over the three years, which could be a real signal. Assuming that the temperature of the environment changed during this time period as seen in the histogram and explained above, the change in salinity from the instantaneous CTD measurements of 0.02 psu over the three years would be associated with the signal. The 
total signal-plus drift in the SBE37 salinity is about 0.08 psu over the three years. Therefore the drift in SBE instruments is about 0.06 psu over the three years or 0.02 psu per year. This change is toward fresher conditions and could be related to cell fouling.

\section{APPENDIX B}

\section{Multiple linear regression model}

Because the CT mooring strings are pulled down by current, as explained in Rabe et al. (2010), the depth of measurement is strongly modulated by tidal currents (many 10s of meters), and less strongly by tidal elevation (several meters). Therefore it was necessary to design an analysis method to remove tidal influence from the time series for each instrument.

Rabe et al. (2010) used linear system analysis to remove signals due to vertical mooring motions at coarse vertical resolution. For this paper we take advantage of the vertical sampling of the water column at tidal period to obtain a higher vertical resolution in salinity and temperature. A simple harmonic analysis is not possible since the measurements were not taken at a fixed point in space. To evaluate the tidal demodulation we developed a model for the temporal variation of salinity using multiple linear regression based on least squares, e.g.,

$$
S(p, t)=s+a t+b p+c p^{2}+d \sin \left(\frac{2 \pi t}{\tau}\right)+e \cos \left(\frac{2 \pi t}{\tau}\right) .
$$

The six unknowns are $a, b, c, d, e$ and $s$. Data required are $S$ for salinity, $p$ for pressure, and $t$ for time at 15-minute time steps. A similar analysis can, of course, be conducted for temperature. The variable $\tau$ is chosen to represent half the dominant period of variation, here the $\mathrm{M}_{2}$ tide; i.e., $0.5 \times 12.42$ hours, since the moorings lean over twice during each tidal cycle, once on the ebb tide and once on the flood. The six unknowns are determined by the method of least squares. Looping through time (stepping forward in three-hour time steps) the overdetermined set of equations is solved using all data acquired over one day, centred at the time of interest, before moving three hours ahead and repeating the procedure, again using 24 hours of data centred at that point to calculate the regression coefficients. The system is solved separately for data from instruments at (1) nominal depths 30,80 and $130 \mathrm{~m}$, and (2) nominal depths 80, 130 and $200 \mathrm{~m}$. Evaluation of the results suggest that minimum errors occur when we switch between regression coefficients (1) and (2) at a depth of $100 \mathrm{~m}$. The resulting set of regression coefficients are then used to reconstruct the data (salinity and temperature) as a function of pressure at the midpoint of each time-window (every three hours).

The model is a simplified representation of the signal recorded by instruments dragged vertically through a salt-stratified water column. It incorporates a quadratic dependence of background salinity on pressure, a possible linear change in background salinity with time (the same at all depths), and a sinusoidal variation of the salinity at twice the nominal semidiurnal frequency. The latter term represents the vertical movement of the sensor through the background field of salinity in response to the ebb and flood of the tide. This simple model of the signal is useful only for short windows in time; we used a window width of 
about two cycles of the semidiurnal tide. The regression analysis provides coefficients that separately represent background and tidal effects. A de-tided field can then be generated simply by substituting values for depth and time using only those coefficients that represent the background field.

The equation represents a compromise between a full representation of the complexity of the signal and a practical regression model that was stable throughout the three-year period of measurement at all sites. The model ignores the diurnal tide. It assumes that the pull-down modulation of salinity is the same at all depths of measurement, even though the sensors higher on the mooring are pulled down a greater distance than those lower down, and even though the change in salinity via pull-down is dependent on the local vertical gradient of salinity. It separately fits the amplitude of the pull-down signal without cross-reference to the vertical gradient embodied in coefficients $b$ and $c$.

Statistics were used to evaluate the goodness of fit after reconstruction of the original data. $R^{2}$ of the unfiltered data is close to 0.98 , and small estimates of error variances around 0.02 indicate high levels of confidence in the regression model. The residuals were of maximum amplitude \pm 0.3 psu but were further reduced to less than 0.1 psu by a Hanning low-pass filter with a window width of 48 hours that was applied to both salinity and temperature.

To reconstruct the data set without a tidal variation (taking out the internal tide) we used all regression coefficients except the sin and cos terms in (4). We reconstructed the data at $1 \mathrm{~m}(1 \mathrm{db})$ resolution. We thus constructed a $S=S(y, p, t)$ data set of salinity that minimizes the sampling bias introduced by mooring motions.

\section{REFERENCES}

Aagaard, K. and E. C. Carmack. 1989. The role of sea ice and other fresh water in the Arctic circulation. J. Geophys. Res., 94, 14485-14498.

Agnew, T. A. 1998. Drainage of multi-year ice from the Lincoln Sea. Can. Meteorol. Oceanogr. Soc. Bull., 26, 101-103.

Ando, K., T. Matsumoto, T. Nagahama, I. Ueki, Y. Takatsuki and Y. Kuroda. 2005. Drift characteristics of a moored conductivity-temperature-depth sensor and correction of salinity data. J. Atmos. Oceanic Technol., 22, 282-291.

Barber, D., R. Marsden, P. Minnett, G. Ingram and L. Fortier. 2001. Physical processes within the North Water NOW Polynya. Atmos.-Oceans, 39, 163-166.

Bourke, R. H., V. G. Addison and R. G. Paquette. 1989. Oceanography of Nares Strait and northern Baffin Bay in 1986 with emphasis on deep and bottom water formation. J. Geophys. Res., 94, 8289-8302.

Copland, L., D. R. Mueller and L. Weir. 2007. Rapid loss of the Ayles ice shelf, Ellesmere Island, Canada. Geophys. Res. Let., 34, L21501, doi: 10.1029/2007GL031809.

Cuny, J., P. B. Rhines and R. Kwok. 2005. Davis Strait volume, freshwater and heat fluxes. Deep-Sea Res., 52, 519-542.

Curry, B., C. M. Lee and B. Petrie. 2011. Volume, freshwater, and heat fluxes through Davis Strait, 2004-2005. J. Phys. Oceanogr., 41, 429-436, doi: 10.1175/2010JP04536.1.

de Steur, L., E. Hansen, R. Gerdes, M. Karcher, E. Fahrbach and J. Holfort. 2009. Freshwater fluxes in the East Greenland Current: A decade of observations. Geophys. Res. Let., 36, doi: 10.1029/2009GL041278. 
Dickson, R., B. Rudels, S. Dye, M. Karcher, J. Meincke and I. Yashayaev. 2007. Current estimates of freshwater flux through Arctic and subarctic seas. Progr. Oceanogr., 73, 210-230.

Dumont, D., Y. Gratton and T. E. Arbetter. 2009. Modeling the dynamics of the North Water Polynya ice bridge. J. Phys. Oceanogr., 39, 1448-1461, doi: 10.1175/2008JP03965.1.

Dunbar, M. 1969. The geographical position of the North Water. Arctic, 22, 438-441.

1973. Ice regime and ice transport in Nares Strait. Arctic, 26, 282-291.

Fissel, D. B., J. R. Birch, H. Melling and R. A. Lake. 1988. Non-tidal flows in the Northwest Passage. Can. Tech. Rep. Hydrogr. Ocean Sci., 98, 143 pp.

Fofonoff, N. P. and H. L. Bryden. 1975. Density of sea waters. J. Mar. Res., 41, 69-82.

Freitag, H. P., M. E. McCarty, C. Nosse, R. Lukas, M. J. McPhadden and M. F. Cronin. 1999. COARE Seacat data: Calibrations and quality control procedures. NOAA Tech. Memo., ERLPMEL-115, $89 \mathrm{pp}$.

Garrett, C. and B. Toulany. 1982. Sea-level variability due to meteorological forcing in the northeast Gulf of St. Lawrence. J. Geophys. Res., 87, 1968-1978.

Hakkinen, S. 1993. An Arctic source for the Great Salinity Anomaly: A simulation of the Arctic ice-ocean system for 1955-1975. J. Geophys. Res., 98, 16397-16410.

1999. Variability of the simulated meridional heat transport in the North Atlantic for the period 1951-1993. J. Geophys. Res., 104, 10991-11007.

Holfort, J., E. Hansen, S. Osterhus, S. Dye, S. Jonsson, J. Meincke, J. Mortensen and M. Meredith. 2008. Freshwater fluxes east of Greenland, in Arctic-Subarctic Ocean Fluxes, Defining the Role of the Northern Seas in Climate, R. R. Dickson, J. Meincke and P. Rhines, eds., Springer, 263-287, doi: 10.1007/978-1-4020-6774-7.

Holland, M. M., J. Finnis, A. P. Barrett and M. C. Serreze. 2007. Projected changes in Arctic Ocean freshwater budgets. J. Geophys. Res., 112, G04S55, doi: 10.1029/2006JG000354.

Holliday, N. P., S. L. Hughes, S. Bacon, A. Beszczynska-Moeller, B. Hansen, A. Lavin, H. Loeng, K. A. Mork, S. Osterhus, T. Sherwin and W. Walczowski. 2008. Reversal of the 1960s to 1990s freshening trend in the northeast North Atlantic and Nordic Seas. Geophys. Res. Let., 35, doi: 10.1029/2007GL032675.

Johnson, H. L. and C. Garrett. 2006. What fraction of a Kelvin wave incident on a narrow strait is transmitted? J. Phys. Oceanogr., 36, 945-954.

Johnson, H. L., A. Münchow, K. K. Falkner and H. Melling. 2011. Ocean circulation and properties in Petermann Fjord, Greenland. J. Geophys. Res., 116, C01003.

Khan, S. A., J. Wahr, M. Bevis, I. Velicogna and E. Kendrick. 2010. Spread of ice mass loss into northwest Greenland observed by GRACE and GPS. Geophys. Res. Let., 37, doi: 10.1029/2010GL042460.

Kliem, N. and D. A. Greenberg. 2003. Diagnostic simulations of the summer circulation in the Canadian Arctic Archipelago. Atmos.-Oceans, 41, 273-289.

Kundu, P. K. and J. S. Allen. 1976. Some three-dimensional characteristics of low-frequency current fluctuations near the Oregon coast. J. Phys. Oceanogr., 6, 181-199.

Kwok, R. 2005. Variability of Nares Strait ice flux. Geophys. Res. Let., 32, L24502, doi: 10.1029/2005GL024768.

Kwok, R., L. T. Pedersen, P. Gudmandsen and S. S. Pang. 2010. Large sea ice outflow into the Nares Strait in 2007. Geophys. Res. Let., 37, doi: 10.1029/2009GL041872.

Kwok, R. and D. A. Rothrock. 1999. Variability of Fram Strait ice flux and North Atlantic Oscillation. J. Geophys. Res., 104, 5177-5189.

Lazier, J. R. N. 1980. Oceanographic conditions at Ocean Weather Ship Bravo, 1964-1974. Atmos.Ocean, 18, 227-238. 
Lindsay, R. and J. Zhang. 2005. The thinning of Arctic sea ice, 1988-2003: Have we passed a tipping point? J. Climate, 18, 4879-4894.

Lindsay, R., J. Zhang, A. Schweiger, M. Steele and H. Stem. JAN 2009. Arctic sea ice retreat in 2007 follows thinning trend. J. Climate, 22, 165-176, doi: 10.1175/2008JCLI2521.1.

Melling, H. 2000. Exchanges of freshwater through the shallow straits of the North American Arctic, in The Freshwater Budget of the Arctic Ocean, E. L. Lewis, E. P. Jones, P. Lemke, T. D. Prowse and P. Wadhams, eds., Springer, 479-502.

- 2004. Fluxes through the northern Canadian Arctic Archipelago. ASOF Newsletter, 2, 3-7.

Melling, H., Y. Gratton and G. Ingram. 2001. Ocean circulation within the North Water polynya of Baffin Bay. Atmos.-Oceans, 39, 301-325.

Mosby, H. 1962. Water, salt and heat balance of the north Polar Sea and of the Norwegian Sea. Geophys. Norv., 24, 289-313.

Münchow, A., K. K. Falkner and H. Melling. 2007. Spatial continuity of measured seawater and tracer fluxes through Nares Strait, a dynamically wide channel bordering the Canadian Archipelago. J. Mar. Res., 65, 759-788.

Münchow, A., K. K. Falkner, H. Melling, B. Rabe and H. L. Johnson. 2011. Ocean warming of Nares Strait bottom waters off Northwest Greenland, 2003-09. Oceanogr., 24, 114-123.

Münchow, A. and H. Melling. 2008. Ocean current observations from Nares Strait to the west of Greenland: Interannual to tidal variability and forcing. J. Mar. Res., 66, 801-833.

Münchow, A., H. Melling and K. K. Falkner. 2006. An observational estimate of volume and freshwater flux leaving the Arctic Ocean through Nares Strait. J. Phys. Oceanogr., 36, 2025-2041.

Parkinson, C. L. and D. J. Cavalieri. 2008. Arctic sea ice variability and trends, 1979-2006. J. Geophys. Res., 113, C07003, doi: 10.1029/2007JC004558.

Peterson, B. J., R. M. Holmes, J. W. McClelland, C. J. Vorosmarty, R. B. Lammers, A. I. Shiklomanov, I. A. Shiklomanov and S. Rahmstorf. 2002. Increasing river discharge to the Arctic Ocean. Science, 298, 2171-2173.

Polyakov, I. V. and M. A. Johnson. 2000. Arctic decadal and interdecadal variability. Geophys. Res. Let., 27, 4097-4100.

Prinsenberg, S. J. and E. B. Bennett. 1987. Mixing and transports in Barrow Strait, the central part of the Northwest Passage. Cont. Shelf Res., 7, 913-935.

Prinsenberg, S. J. and J. Hamilton. 2005. Monitoring the volume, freshwater and heat fluxes passing through Lancaster Sound in the Canadian Arctic Archipelago. Atmos.-Ocean, 43, 1-22.

Proshutinsky, A., R. Krishfield, M.-L. Timmermans, J. Toole, E. Carmack, F. McLaughlin, W. J. Williams, S. Zimmermann, M. Itoh and K. Shimada. 2009. Beaufort Gyre freshwater reservoir: State and variability from observations. J. Geophys. Res., 114, doi: 10.1029/2008JC005104.

Rabe, B., A. Münchow, H. L. Johnson and H. Melling. 2010. Nares Strait hydrography and salinity field from a three-year moored array. J. Geophys. Res., 115, C07010. doi: 10.1029/2009JC005966.

Rabe, B., U. Schauer, A. Mackensen, M. Karcher, E. Hansen and A. Beszczynska-Möller. 2009. Freshwater components and transports in the FRAM Strait: Recent observations and changes since the late 1990s. Ocean. Sci., 5, 219-233.

Rasmussen, T. A. S., N. Kliem and E. Kaas. 2010. Modelling the sea ice in the Nares Strait. Ocean Model., 35, 161-172, doi: 10.1016/j.ocemod.2010.07.003.

Rennermalm, A. K., E. F. Wood, S. J. Dery, A. J. Weaver and M. Eby. 2006. Sensitivity of the thermohaline circulation to Arctic Ocean runoff. Geophys. Res. Let., 33, doi: 10.1029/2006GL026124.

Rignot, E. and K. Steffen. 2008. Channelized bottom melting and stability of floating ice shelves. Geophys. Res. Let., 35, L02503, doi: 10.1029/2007GL031765.

Rigor, I. G., J. M. Wallace and R. L. Colony. 2002. Response of sea ice to the Arctic Oscillation. J. Climate, 15, 2648-2663. 
Rudels, B. 1986. The outflow of polar water through the Arctic Archipelago and the oceanographic conditions in Baffin Bay. Polar Res., 4, 161-180.

- 2011. Volume and freshwater transports through the Canadian Arctic Archipelago-Baffin Bay system. J. Geophys. Res., 116, doi: 10.1029/2011JC007019.

Sadler, H. E. 1976. Water, heat, and salt transport through Nares Strait, Ellesmere Island. J. Fish. Res. Board Can., 33, 2286-2295.

Samelson, R. M., T. Agnew, H. Melling and A. Münchow. 2006. Evidence for atmospheric control of sea-ice motion through Nares Strait. Geophys. Res. Let., 33, L02506, doi: 10.1029/2005GL025016.

Samelson, R. M. and P. L. Barbour. 2008. Low-level winds in Nares Strait: A model-based mesoscale climatology. Mon. Weather Rev., 136, 4746-4759.

Schauer, U., E. Fahrbach, S. Østerhus and G. Rohardt. 2004. Arctic warming through the Fram Strait: Oceanic heat transport from 3 years of measurements. J. Geophys. Res., 109, doi: 10.1029/2003JC001823.

Serreze, M. C., A. P. Barrett, A. G. Slater, R. A. Woodgate, K. Aagaard, R. B. Lammers, M. Steele, R. Moritz, M. Meredith and C. M. Lee. 2006. The large-scale freshwater cycle of the Arctic. J. Geophys. Res., 111, CllOIO, doi: 10.1029/2005JC003424.

Serreze, M. C. and J. A. Francis. 2006. The Arctic amplification debate. Clim. Change, 76, 241-264.

Steele, M., D. Thomas, D. Rothrock and S. Martin. 1996. A simple model study of the Arctic Ocean freshwater balance, 1979-1985. J. Geophys. Res., 101, 20833-20848.

Stouffer, R., J. Yin, J. Gregory, K. Dixon, M. Spelman, W. Hurlin, A. J.Weaver, M. Eby, G. M. Flato, H. Hasumi, A. Hu, J. H. Jungclaus, I. V. Kamenkovich, A. Levermann, M. Montoya, S. Murakami, S. Nawrath, A. Oka, W. R. Peltier, D. Y Robitaille, A. Sokolov, G. Vettoretti and S. L. Weber. 2006. Investigating the causes of the response of the Thermohaline Circulation to past and future climate changes. J. Climate, 19, 1365-1387.

Straneo, F. and F. Saucier. 2008. The outflow from Hudson Strait and its contribution to the Labrador Current. Deep-Sea Res., Part I, 55, 926-946, doi: 10.1016/j.dsr.2008.03.012.

Stroeve, J. C., M. C. Serreze, F. Fetterer, T. Arbetter, W. Meier, J. Maslanik and K. Knowles. 2005. Tracking the Arctic's shrinking ice cover: Another extreme September minimum in 2004. Geophys. Res. Let., 32, doi: 10.1029/2004GL021810.

Timmermans, M.-L., A. Proshutinsky, R. A. Krishfield, D. K. Perovich, J. A. Richter Menge, T. P. Stanton and J. M. Toole. 2011. Surface freshening in the Arctic Ocean's Eurasian Basin: An apparent consequence of recent change in the wind-driven circulation. J. Geophys. Res., 116 (COOD03), doi: 10.1029/2011JC006975.

Timofeev, V. T. 1960. Water Masses of the Arctic Basin (in Russian), Gydrometeoizdat, Leningrad.

Vincent, R. F. and R. F. Marsden. 2001. An analysis of the dissolution of ice in Nares Strait using AVHRR Imagery. Atmos.-Oceans, 39, 209-222. doi: 10.1080/07055900.2001.9649677.

White, D., L. Hinzman, L. Alessa, J. Cassano, M. Chambers, K. Falkner, J. Francis, W. J. Gutowski, M. Holland, R. M. Holmes, H. Huntington, D. Kane, A. Kliskey, C. Lee, J. McClelland, B. Peterson, T. S. Rupp, F. Straneo, M. Steele, R. Woodgate, D. Yang, K. Yoshikawa, and T. Zhang. 2007. The Arctic freshwater system: Changes and impacts. J. Geophys. Res., 112, G04S54. doi: 10.1029/2006JG000353.

Wu, P., H. Haak, R. Wood, J. Jungclaus and T. Furevik. 2008. Simulating the terms in the Arctic hydrological budget, in Arctic-Subarctic Ocean Fluxes, R. R. Dickson, J. Meincke and P. Rhines, eds., Springer, 363-384.

Yao, T. and C. Tang. 2003. The formation and maintenance of the North Water Polynia. Atmos.Oceans, 41, 187-201. 